\title{
Contribuições da Concepção Instintiva da Linguagem inerente à Biolinguística e à Linguística Evolucionária para as Pesquisas da Psicolinguística
}

\author{
Contributions of Instinctive Conception of Language inherent to Biolinguistics and to Evolutionary Linguistics \\ for The Psycholinguistics Research
}

\section{Pablo Machel Nabot Silva de Almeida}

Universidade Federal da Paraíba - UFPB - João Pessoa - Paraíba - Brasil

\begin{abstract}
$\longrightarrow$
Resumo: Este artigo discute como a hipótese de que a linguagem faz parte de nossos instintos naturais tal como proposta contemporaneamente dentro da Linguística Evolucionária por Pinker e Bloom (1990) e Pinker (2002) os quais a defendem como um instinto tal qual concebido inicialmente por Darwin (1871) no domínio da Biologia Evolucionista, sob os preceitos da Biolinguística strictu sensu (MEADER; MUYSKENS, 1962) e da Linguística Evolutiva, a qual se embasa na Teoria Evolucionista da Seleção Natural (DARWIN, 2003), pode contribuir para o desenvolvimento teórico-metodológico da Psicolinguística (OSGOOD; SEBEOK, 1954a). Porfia-se sobre como tal concepção pode favorecer a descrição dos fenômenos psicolinguísticos subjacentes à atividade cognitiva, assim como a explicação dos princípios cognitivos inerentes ao exercício da faculdade da linguagem. Para tanto, contemplar-se-á, inicialmente, uma análise histórica e uma caracterização de duas importantes áreas especializadas da Linguística intimamente harmonizadas com a vertente gerativista ou Linguística Ge(ne)rativa (CHOMSKY, 1957, 1975): a Psicolinguística (OSGOOD; SEBEOK, 1954a, 1954b, 1965) e a Biolinguística (MEADER; MUYSKENS, 1962) para que possa então haver, na sequência, a discussão de como a conceptualização instintiva da linguagem é capaz de subsidiar o desenvolvimento da Psicolinguística. Em suma, averiguar-se-á o potencial que esses campos interdisciplinares possuem para permitir uma teoria de aquisição da linguagem e do processamento que tenha suas diretrizes e princípios definidores respaldados nos fatores os quais possibilitaram o nascimento e evolução da linguagem e nas bases biológicas que viabilizaram e que continuam viabilizando esse processo ao longo do tempo.
\end{abstract}

Palavras-chave: Biolinguística. Psicolinguística. Linguística Evolucionária ou Evolutiva. Concepção Instintiva da Linguagem e Seleção Natural. Contribuições da Concepção Instintiva da Linguagem para a Psicolinguística.

\begin{abstract}
This article discusses how the hypothesis that language is part of our natural instincts as proposed contemporaneously in Evolutionary Linguistics by Pinker and Bloom (1990) and Pinker (2002) who defend it as an instinct such as originally conceived by Darwin (1871) in the field of Evolutionary Biology, under the precepts of Biolinguistics strictu sensu (MEADER; MUYSKENS, 1962) and Evolutionary Linguistics, which is based on the Evolutionary Theory of Natural Selection (DARWIN, 2003), can contribute to the theoreticalmethodological development of Psycholinguistics (OSGOOD; SEBEOK, 1954a). It is argued how such a conception can favour the description of the psycholinguistic phenomena underlying the cognitive activity, as well as the explanation of the cognitive principles inherent to the exercise of the language faculty. In order to do so, initially it will be considered a historical analysis and a characterization of two important specialized areas of Linguistics closely aligned with the Generativism or Generative Linguistics (CHOMSKY, 1957, 1975): Psycholinguistics (OSGOOD; SEBEOK, 1954a, 1954b, 1965) and Biolinguistics (MEADER; MUYSKENS, 1962) so that there can then be, in the sequence, the discussion of how instinctive conceptualization of language is able to subsidize the development of Psycholinguistics. In sum, it will be checked the potency that those interdisciplinary fields to Psycholinguistics have so as to let a theory of language acquisition and processing which has its guidelines and defining principles supported over the factors that allowed the birth and evolution of the language and on the biologic bases which enabled and that continue facilitating that process along the time.
\end{abstract}

Keywords: Biolinguistics. Psycholinguistics. Evolutionary Linguistics. Instinctive Conception of Language and Natural Selection. Contributions of Instinctive Conception of Language to Psycholinguistics. 


\section{Introdução}

A vivaz preocupação juntamente com a impetuosa vontade de se estudar a linguagem remonta há bastante tempo, isto é, a um passado distante da história humana que data da Antiguidade, quer seja a demarcação de tal época considerada a partir das investigações filológicas da linguagem de tradição oriental conduzidas inicialmente na Índia em torno dos estudos analíticos (Vyãkarana) dos textos religiosos dos "Vedas" os quais se materializaram por meio da elaboração feita por Yãska do mais antigo tratado sobre linguagem intitulado de "Nirukta" (Explanação), assim como por intermédio da principal obra de descrição minuciosa do sânscrito elaborada por Pãnini no século IV a.c. cuja detalhada explicação foi fornecida por Pantañjali no século II a.c. através do "Mahãbhãsya" (Grande Comentário); quer seja a datação da referida era contabilizada desde os trabalhos filosóficos da linguagem de herança ocidental desenvolvidos pelos pré-socráticos na Grécia Antiga a contar primeiramente com a elaboração da teoria do "Logos" (A Palavra) propriamente vinculada a Heráclito de Éfeso da filosofia panteística da Escola Jônica, a qual foi seguida, tamanha teoria, dos conceitos de Parmênides de Eleia da filosofia da Escola Eleática entre os séculos VI e V a.c., bem como daqueles de Demócrito de Abdera da filosofia inerente à Escola Atomista entre os séculos $V$ e IV a.c. e dos de Epicuro de Samos da filosofia da Escola Epicurista entre os séculos IV e III a.c. os quais versaram sobre temas linguísticos, afora o que no que concerne aos exames sobre a linguagem perpetrados por Platão especialmente por via do seu diálogo do "Crátilo" e por Aristóteles através de seu "Perì Hermeneías" por volta do século IV a.c. (cf. CAMARA JÚNIOR, 2011, p. 22-29; FONSECA, 2009). Entretanto, apenas mais recentemente, em termos históricos, o estudo da linguagem propôs-se a assumir um caráter científico, como também mais empírico - e, portanto, menos normativo e não somente etimológico, filológico, filosófico e/ou teológico, como tivera sido anteriormente, desde os primórdios -, a partir do advento da ciência dedicada a isso, à investigação da linguagem e das línguas naturais humanas, a saber, a Linguística. Esta assim então foi batizada e passou a ser denominada pela comunidade científica, tendo-se estruturado sob a égide de sua primeira forma de manifestação e organização teórico-metodológica em torno de uma escola de tradição clássica que ficou reconhecida como Linguística Histórico-Comparativa (ou Filologia em sentido estrito) no século XIX, um verdadeiro marco para as inquirições idiomáticas (FURTADO DA CUNHA; COSTA; MARTELOTTA, 2012).

Ora, o Comparativismo, como também esta primeira escola clássica é nomeada, correspondeu à primeira corrente revolucionária em se tratando dos estudos linguísticos, ao quebrar barreiras, superando tendências normativas de cunho praticamente imutável, bem como o preconceito e arbitrariedade do tradicionalismo gramatical, vigente até então, através da presença dominante dos preceitos da Gramática Tradicional ou Normativa os quais perduravam desde a tradição gramatical grega (ainda bastante difundida hoje em dia, principalmente nos ritos das instituições oficiais, a exemplo das escolas e órgãos públicos). Também revolucionou ao conferir uma postura mais técnica, alicerçada nos fundamentos do tecnicismo, da observação sistemática, da experimentação ou empirismo e, é óbvio, da ciência conjuntamente com o rigor o qual é próprio das diretrizes que são tomadas e delineadas pelo método experimental por esta conduzido (CAMARA JÚNIOR, 2011; MARTELOTTA, 2012).

Da mesma forma, no início do século $X X$, a Linguística passa por mais uma reviravolta conceptual e metodológica, uma genuína e nova revolução com a emersão das teorias linguísticas do linguista suíço Ferdinand de Saussure (2006) as quais compuseram as bases não só do conteúdo constituidor, mas também da sistemática formativa e modeladora de uma nova Linguística ou, em outras palavras, de uma nova escola teórica a qual foi nomeada de Linguística Estrutural ou Estruturalismo (SAUSSURE, 2006), de maneira tal que ela marcou o surgimento de uma nova era, sendo a gramática estrutural a instituidora 
da Linguística Moderna e sua primeira representante dentre as correntes linguísticas, caracterizando-se como um divisor de águas entre a fase inicial clássica dos estudos histórico-comparativos e dessa outra moderna etapa das pesquisas estruturalistas que também se desdobraram nos Estados Unidos a partir de Bloomfield (1965) sob uma diferente variação do Estruturalismo Europeu, intitulada de Distribucionalismo, como ficou conhecido o Estruturalismo Norte-Americano o qual, apesar de preservar a mesma essência que a permite ser inserida dentro do contexto de uma escola estrutural, mantém diferenças em relação àquela de caráter saussuriano (COSTA, 2012; MARTELOTTA, 2012).

Assim, após o nascimento e afirmação desse moderno estágio de configuração da Linguística enquanto ciência com a sedimentação da linha estruturalista (SAUSSURE, 2006; BLOOMFIELD, 1965), uma série de outros ramos ou doutrinas ${ }^{1}$ apareceram para tentar dar conta das misteriosas e nebulosas questões que vez ou outra surgiam em face dos problemas ou dúvidas relativos à linguagem que se intentavam solucionar. Como exemplo disso, tem-se, desde as primeiras décadas do século XX, o desenvolvimento e impulso da Fonologia Estrutural juntamente com a Linguística Funcional ou Funcionalismo, oriunda das inquirições efetuadas pelo Círculo Linguístico de Praga sob a liderança de Vilém Mathesius em 1926 de onde brotaram expoentes da área tais como Roman Jakobson, Nikolaj Trubetzkoy e André Martinet. Em seguida, observa-se a modelagem e, consecutivamente, a formação da Linguística Gerativa ou Gerativismo, emergente das ideias e apurações do ativista político, cientista cognitivo, filósofo e linguista estadunidense Noam Chomsky, vindas a público com a publicação de seu livro "Estruturas Sintáticas" ("Syntactic Structures-SS") em 1957 (FERRARI-NETO; SILVA, 2012; FURTADO DA CUNHA, 2012; KENEDY, 2012; MARTELOTTA, 2012).

Além do mais, concomitantemente à construção e consolidação da gramática gerativa,

\footnotetext{
1 Pontue-se que a designação "doutrina" cá se refere ao conjunto de princípios que compõem, fundamentam e regem o sistema ideológico de determinada escola linguística.
}

outras variedades de ideais e constructos teóricos inerentes às investigações acerca dos sistemas linguísticos típicos dessa ciência-mãe ou disciplina maior, a Linguística, nasceram com crenças, propósitos e focos de pesquisa bem específicos, em parte ora convergentes ora divergentes, a fim de tentar resolver novas problemáticas ou intrigas referentes ao progresso desse saber científico em pauta. É o caso, por exemplo, da Psicolinguística, da Biolinguística, da Neurolinguística e da Linguística Evolucionária ou Evolutiva as quais firmaram sua existência como subdivisões doutrinárias ou ramificações especializadas dela, da linguística, em meio aos campos de saberes humanos.

Do mesmo jeito, seguindo-se ao crescimento e acomodação da gramática gerativo-transformacional, tempos depois, outras subáreas com seus próprios modelos teórico-metodológicos tomaram forma e se estabeleceram como setores profícuos da atividade intelectual e propiciadores do avanço das ciências linguísticas. Dentre essas ramificações é possível citar, a fim de servir de exemplo, o Funcionalismo Norte-Americano, o Sociofuncionalismo, a Linguística Cognitiva e Sociocognitiva (o Sociocognitivismo ou simplesmente Cognitivismo), a Linguística Sociointeracionista (o Sociointeracionismo ou Interacionismo), o Interacionismo Sociodiscursivo (ISD), a Linguística Construtivista e/ou Socioconstrutivista, a Linguística Sistêmico-Funcional, a Linguística Textual, a Linguística Enunciativa, a Linguística Discursiva, a Análise do Discurso (AD), a Análise Crítica do Discurso (ACD), a Análise Dialógica do Discurso (ADD, Dialogismo ou Linguística Dialógica), a Análise da Conversação (AC), a Política Linguística, a Sociolinguística, a Dialetologia ou Dialectologia, a Etnolinguística (ou Antropolinguística ou ainda Linguística Antropológica), a Ecolinguística e a Geolinguística ou Linguística Geográfica, a Linguística Indo-Europeia ou a Indo-Europeística, a Linguística Indígena ou Ameríndia, a Linguística Africana, a Linguística Americana, a Linguística Asiática, a Linguística Oceânica, a Linguística Aplicada, a Psicolinguística Aplicada, a Aquisição da Linguagem, a Linguística 
Histórica, a Linguística Forense e Jurídica, a Linguística Computacional, a Linguística Genética intimamente vinculada à Linguística Evolucionária, a Linguística Animal, a Lexicologia, Lexicografia e Terminologia, entre outros subcampos especializados como a Linguística de Corpus e as novas Linguística Funcional Centrada no Uso ou Linguística CognitivoFuncional, Linguística Educacional, Linguística Clínica, Linguística da Paz, Astrolinguística, Exolinguística e/ou Linguística Alienígena, além da Teolinguística e da Politolinguística ou Linguística Política, mais recentemente originadas no interior e cerne da sociedade científica mundial (CEZARIO; MARTELOTTA, 2012; CEZARIO; VOTRE, 2012; LEITÃO, 2012; MARTELOTTA, 2012; MARTELOTTA; PALOMANES, 2012; OLIVEIRA, 2012; OLIVEIRA; WILSON, 2012, dentre outros).

Sendo assim, em virtude dessa vastidão de especializações pelas quais essa ciência em questão tem passado ao longo do tempo, dos últimos dois séculos, especialmente durante o século $X X$ e de modo mais particular e preciso nos derradeiros cinquenta anos, faz-se mister pensar, refletir, debater e discutir o encaminhamento de cada um desses setores e de seus singulares princípios, principalmente em razão da grande quantidade de interfaces que se pode notar existir no seio deles, dentro do contexto mais amplo e unificador da ciência-mor, a Linguística, a qual foi e é a geradora e, mais que isso, a genitora de cada um deles, em última análise, dentro do contexto acadêmicocientífico em que se está inserido.

Logo, tendo em vista essa situação, da imensa diversidade de áreas componentes da Linguística, não havendo condições didáticas nem espaço para meditar cada uma dessas disciplinas nem sua inter-relação, o presente artigo restringir-se-á a delimitar a análise de apenas algumas dessas esferas, a saber, a Psicolinguística e a Biolinguística, estando esta avaliada sob o escopo da Linguística Evolucionária ou Evolutiva e mais estritamente da hipótese instintiva da linguagem tal como defendida e atualizada no seio dos estudos linguísticos desencadeados por Pinker e Bloom (1990) e Pinker (2002).

Procurar-se-á, então, demonstrar como os princípios subjacentes a essa concepção instintiva do fenômeno linguístico inerente ao evolucionismo característico da Seleção Natural de Darwin (2003) podem ser úteis para a formulação de leis gerais explicativas dos processos mentais e cognitivos que possibilitam e permeiam tanto a capacidade quanto a compreensão e produção em si da linguagem, naturalmente dinâmica e em pleno uso cotidiano humano $^{2}$, seja qual for a língua tomada em específico.

Para tanto, apresentar-se-á primeiramente uma breve exposição do arcabouço teórico da Psicolinguística e quais são seus conceitos e funções no tangente aos processos comunicativos humanos. Logo após, no tópico seguinte, mostrar-se-á, nos mesmos moldes, o esboço teorético da Biolinguística tanto em seu sentido lato, enquanto projeto linguístico atrelado ao programa da Linguística Gerativa, quanto em seu sentido estrito, tal como disciplina especializada e independente dentro do campo da Ciência Linguística, apresentando-se, de igual maneira, quais são seus fundamentos e intentos no concernente à aptidão linguística humana. A seguir, no terceiro e principal ponto, notadamente o central, proceder-se-á com a análise de como a linguagem, vista como um instinto inerentemente vinculado ao homem a partir da perspectiva da Linguística Evolucionária que está intimamente integrada à Biolinguística strictu sensu (i.e. à biolinguística enquanto disciplina ou subárea) pode contribuir em grande parcela para o entendimento dos constructos e fenômenos psicolinguísticos.

Por fim, serão tecidas as considerações finais em que se resumirá o que de mais importante tem sido pautado pela extensão do texto, enfatizando-se a extrema importância de se manter constantemente um diálogo produtivo entre todos esses subsetores da Linguística, com atenção especial para o vínculo

\footnotetext{
2 Esclareça-se que a linguagem que é tanto compreendida quanto produzida detém uma dimensão dinâmica por se constituir em uma linguagem em uso e plenamente operante tanto em seus patamares biológico como social os quais a perpassam.
} 
passível de se fortalecer entre a Psico e a Bio juntamente com a Linguística Evolucionária, e até mesmo entre outras ciências ou campos do saber, como as Neurociências, a Biologia, a Genética e Engenharia Genética, a Medicina e a Neurologia, a Nanotecnologia, a Antropologia, a Paleontologia, a Arqueologia e a Filosofia por exemplo.

\section{A Psicolinguística}

A Psicolinguística corresponde à subárea da Linguística cujos fundamentos e constructos teórico-metodológicos tanto se constituíram quanto se delinearam a partir da interface que passou e veio a ser instituída entre as Ciências Linguísticas e a Psicologia, especialmente a Psicologia Cognitiva, em meados do século XX (HARLEY, 2008; MAIA, 2015).

$O$ interesse central, pois, dessa área reside em três quesitos essenciais, a saber, (1) compreender como os seres humanos adquirem a linguagem verbal, (2) como as pessoas a produzem e, por derradeiro, (3) como elas a compreendem. Os estudos relativos àquela, isto é, à primeira questão compreendem o campo da Psicolinguística Desenvolvimentista que abarca as investigações sobre a Aquisição da Linguagem ao passo que os referentes a estas, as duas últimas, compõem a Psicolinguística Experimental a qual trata de descrever e explicar quais são as habilidades cognitivas vinculadas à linguagem e quais recursos ou procedimentos mentais/cognitivos são empregados pela psique e/ou cognição humana para permitir que o ser humano seja apto a compreender e produzir a linguagem articulada por meio de um conjunto de operações psíquicas e/ou cognitivas, altamente complexas e sofisticadas, denominado de processamento linguístico (LEITÃO, 2012, p. 220222; confronte com PETERFALVI, 1970).

De efeito, segundo elenca Peterfalvi (1970, p. 31), a Psicolinguística propõe-se, de acordo com uma primeira definição que segue a proposta conceituadora inaugural de seus fundadores (OSGOOD; SEBEOK, 1954a), especificamente ao estudo dos processos de codificação e de descodificação da linguagem, levando-se em conta as características típicas dos sujeitos humanos que naturalmente promovem a troca de mensagens de tal sorte que a investigação desses processos relacionem os estados de uma mensagem com os estados dos interlocutores. Indo além, conforme uma segunda definição posterior coadunada ao gerativismo linguístico chomskyano, a Psicolinguística objetiva primordialmente, consoante pontua Peterfalvi (1970, p. 37-38), construir e validar um modelo de performance linguística que precise de que maneira o desempenho linguístico humano procede a partir do modo como a competência linguística do homem funciona estando sob a ação direta de diversas restrições cognitivas e inerentemente psicológicas tais como a memória, memória de trabalho, percepção, atenção, etc., que afetam o funcionamento da linguagem em tempo real, estando atuantes e presentes, pois, seja em sua aquisição seja em seu processamento e consequentemente em seus processos de produção e percepção do discurso e/ou input linguístico ${ }^{3}$ (ver ALTMANN, 2001, 2006

3 Em verdade, muito embora o objeto de estudo da Psicolinguística se constitua como sendo a performance linguística, i.e., seu desempenho em tempo real que compreende tanto a aquisição quanto o processamento on-line, certos psicolinguistas são mais enfáticos em afirmar que a competência, então objeto exclusivo da Linguística, também pode ser enquadrada como objeto e foco de investigação da própria Psicolinguística (PICHEVIN, 1968 apud PETERFALVI, 1970 , p. 38), haja vista que esta se interessa notoriamente pela evolução ontogenética da linguagem a ponto de buscar compreender a aquisição progressiva da própria competência linguística. Como a competência e a performance são essencialmente indissociáveis na manifestação linguística, uma vez que uma decorre da outra e nenhuma das duas existe por si só pelo fato de o desempenho se alicerçar na competência para se conformar e/ou viabilizar enquanto fenômeno e a competência necessitar da performance para poder se materializar concretamente a partir de sua abstração simbólica de algoritmos e regras, considera-se que a Psicolinguística e a Linguística detêm o mesmo objeto de estudo e os mesmos propósitos, havendo a defesa, até por parte de uns, de que não há mais diferença entre uma disciplina e outra. Isso procede justamente porque tem havido um ponto de convergência entre ambas verificável no fato de que a Linguística, apesar de ser formal, tem evoluído para um modelo de concepção de língua caracterizado enquanto fenômeno psicológico à proporção que a Psicolinguística, apesar de centrada no desempenho linguístico, tem buscado estudar e explicar essa performance a partir dos modelos abstratos de competência fornecidos pela Linguística, sendo esta a razão pela qual se tem procurado estabelecer uma fusão plena entre as duas disciplinas - que ainda não se completou, frise-se - de maneira tal que ambas se confundam e/ou venham a se confundir (cf. PETERFALVI, 1970 , p. 38). A propósito, uma tentativa novel em se alcançar esse objetivo é discutida hodiernamente por Lewis e Phillips (2015) que apresentam alternativas e mecanismos para alinhar as teorias gramaticais da Linguística e os modelos de processamento da linguagem inerentes à Psicolinguística. 
para uma revisão da história e da origem da Psicolinguística $\left.{ }^{4}\right)$.

A propósito, como aponta Scliar-Cabral (1991, p. 8-10), os antecedentes do surgimento da Psicolinguística remontam ao século XIX com os estudos e reflexões desencadeados pelo linguista e filósofo alemão Humboldt, o Barão W. von Humboldt, o qual fez a distinção entre ergon e energeia ao salientar os dois aspectos distintos demonstrados pela linguagem, o de se configurar como produto (ergon), o qual se tornaria o objeto da linguística a partir de F. de Saussure (2006), e como processo (energeia), correspondendo à capacidade do espírito humano de utilizar sons articulados para se comunicar e se expressar, o que viria a ser um dos objetos da futura psicolinguística. Suas ideias, imbuídas de um admirável vislumbre futurista, foram tão influentes e pioneiras que exerceram forte e imediato impacto, na época, sobre os linguistas alemães Heymann Steinthal, pupilo de Humboldt, e Hermann Paul, além do que perante o filósofo e psicólogo também alemão Wilhelm Wundt - o qual se preocupava com as implicações dos processos mentais diante do comportamento verbal e que fundou 0 primeiro laboratório de psicologia experimental na Alemanha - e, mais de um século depois, ainda operavam também influência sobre o filósofo e linguista americano Noam Chomsky (cf. LEITÃO, 2012, p. 217-218).

Ademais, conforme pontuado por Corrêa (2005, p. 224-225), a Psicolinguística, na condição de

\footnotetext{
4 Percorra também Christiansen e Chater (2001) para uma revisão da história do desenvolvimento do campo segundo a diferente abordagem emergente da Psicolinguística Conexionista que implementa modelos computacionais conexionistas que aproximam cada vez mais a Psico da Linguística Computacional a qual, por seu turno, também está mais e mais intimamente entremeada à Linguística Evolucionária em seus métodos e epistemologia. Sonde, de igual modo, Kess (1991) para uma revisão histórica sobre o desenvolvimento da Psicolinguística e consulte, outrossim, Murray (1990) para tomar ciência da grande importância que o linguista alemão Clemens Knobloch (1951-) exerceu sobre o desenvolvimento da história da Psicolinguística ao investigar minuciosamente as contribuições para o setor antes de seu histórico período formativo, em tendo sido tais colaborações desencadeadas por destacados escritores alemães entre os séculos XIX e XX, especificamente entre os anos de 1850 e 1920. Por fim, compulse O'Connell e Kowal (2003) para uma revisão crítica da história da Psicolinguística por ter sido ela considerada por meio século monológica, tendo em vista a proposta dos autores para uma visão mais dialógica frente a ela.
}

teoria do processamento linguístico da maneira como hoje é concebida, surgiu de uma vertente da Psicologia dedicada exclusivamente ao processamento do sinal da fala e ao papel estruturador da língua frente à memória de curto-prazo (MILLER, 1951; MILLER; SELFRIDGE, 1950), por intermédio de sua aproximação com a Linguística $^{5}$ (MILLER; CHOMSKY, 1963); de maneira tal que, após a Segunda Guerra Mundial, conjuntamente com a necessidade de se desenvolver um conhecimento robusto sobre os sistemas de comunicação, que levou à estruturação da Teoria da Informação de Shannon e Weaver (1963), em um dado momento, sentiu-se que essas três ciências - a Linguística, a Psicologia e a Ciência da Informação não poderiam prosseguir suas pesquisas, e cada um de seus avanços técnico-científicos, em isolado (q.v. SCLIAR-CABRAL, 1991, p. 12-13; compare também PETERFALVI, 1970 , p. 14-29 que discute a contribuição da Linguística e da Teoria da Informação para o nascimento da Psicolinguística).

Era necessário, portanto, que linguistas, psicólogos e cientistas da informação, por exemplo, se unissem e se apoiassem mutuamente em prol de perseguirem certos objetivos em comum a fim de que pudessem atingir as metas ou resultados almejados, o que culminou na realização de um importantíssimo pré-evento de inauguração da nova área científica a qual foi batizada pelo nome de 'Psicolinquística': o "Seminário de Verão de Pesquisa Interuniversitária da Universidade de Cornell", realizado de 18 de junho a

\footnotetext{
5 Mister se faz destacar que a aproximação entre esses três domínios se deu em uma fase de paradigmas vigentes à época que são distintos dos atuais para que houvesse o nascimento da então nova área da Psicolinguística. Excetuando-se o campo da Teoria da Informação vinculada às Engenharias, quando a Linguística e a Psicologia se associaram cooperativamente, reinava dentro desta o paradigma científico do Behaviorismo de Skinner e naquela o Estruturalismo de Saussure, impulsionado pelos estudos da Fonologia Estrutural de Jakobson e Trubetzkoy, tendo a primeira fase da Psicolinguística sido quer influenciada quer marcada pela tradição tanto estruturalista da Linguística quanto comportamentalista/behaviorista da Psicologia da época. Só posteriormente, a partir da Revolução Cognitiva (ver MILLER, 2003 que trata da perspectiva histórica desta revolução e especificamente sobre o nascimento da Ciência Cognitiva na p. 143), com o advento do cognitivismo como paradigma preponderante dentro da Psicologia e do Gerativismo dentro da Linguística, é que a Psicolinguística, de sua segunda fase em diante, começou a beber ora mais da Psicologia Cognitiva ora mais da Linguística Gerativa ou então de ambas de forma mais ou menos equilibrada e uniforme tal como tem sido na fase atual (cf. PETERFALVI, 1970, p. 13-40; SCLIAR-CABRAL, 1991, p. 8-17).
} 
10 de agosto de 1951, sob a coordenação do psicólogo John Bissell Carroll (um proeminente discípulo de Benjamin Lee Whorf e membro da Universidade de Harvard), que reuniu psicólogos e linguistas do mundo inteiro tal como muito bem frisado por Scliar-Cabral (1991, p. 13-14) e por Harley (2008, p. 9-10).

Finalmente, de acordo com o que se é esclarecido por Balieiro-Jr. (2006, p. 171-201), o nascimento oficial da disciplina ocorreu dois anos depois durante o seu período formativo, consoante divisão e classificação histórico-constitutiva estabelecida por Maclay (1973 apud KESS, 1991, p. 5), tendo sido creditado ao segundo "Seminário de Verão sobre Psicolinguística da Universidade de Indiana", em 1953, o qual foi coordenado pelo psicólogo da Universidade de Illinois, Charles Egerton Osgood, sob o financiamento do Social Science Research Council (SSRC) e fundos da Carnegie Corporation of New York o qual resultou na primeira publicação acadêmico-científica da nova área recém-formada a partir do trabalho compilador de seus fundadores, quais sejam, Osgood e Sebeok (1954a) (cf. BALIEIRO-Jr., 2006, p. 175-176; KESS, 1991, p. 5-8; OSGOOD; SEBEOK, 1954b, 1965; PETERFALVI, 1970, p. 14-15; SCLIAR-CABRAL, 1991, p. 9-17).

\section{A Biolinguística}

É preciso esclarecer, antes de mais nada, que o termo biolinguística carrega em si uma carga semântica dual e, porquanto, diversificada, podendo ser concebida, assim, de duas maneiras distintas: em torno de um sentido de natureza mais estrita e em derredor de outro de caráter mais abrangente, ou seja, há a caracterização de uma biolinguística lato sensu e de outra strictu sensu.

Nesses termos, a biolinguística, em seu sentido amplo, conforme frisado por Boeckx e Grohmann (2007), corresponde ao projeto ou perspectiva do gerativismo linguístico que, em larga medida, inicialmente começou a tomar forma e medrou a partir da obra "Syntactic Structures-SS"
(“Estruturas Sintáticas-ES") de Chomsky (2002) a qual emergiu em 1957 de um conjunto de anotações para um curso que ele proferiu no Massachusetts Institute of Technology-MIT (Instituto de Tecnologia de Massachusetts) para um público de engenheiros e que compilava alguns resultados primordiais obtidos por ele na sua então ainda não publicada tese de doutorado "Logical Structure of Linguistic TheoryLSLT" ("Estrutura Lógica da Teoria da Linguagem") de 1955 (CHOMSKY, 1975) ao enfatizar os aspectos-chaves das propriedades combinatoriais da gramática. Daí, decorre que as ideias veiculadas em SS constituíram-se nas responsáveis por propagar importante mensagem subliminar que, embora ainda implícita e um tanto opaca à época no tocante ao seu viés e projeto biolinguístico, se revelou mais explícita na clássica revisão de Chomsky (1959) sobre a obra "Verbal Behavior" de Skinner (1957) e ainda mais evidentemente no capítulo 1 de "Aspects of The Theory of Syntax" ("Aspectos da Teoria da Sintaxe") de Chomsky (1965), qual seja, de que o empreendimento gerativo se centraria em identificar as propriedades da faculdade da linguagem do ser humano como correspondente à própria caracterização da linguagem humana em última análise, a ponto de isto se constituir como o ponto central de seu programa, o que decerto confere um caráter claramente psicológico e de respaldo essencialmente biológico à Linguística Gerativa (ver PELLEGRINO, 2011, p. 31-33; confronte também CHOMSKY, 2007a, 2007b, 2007c).

Então, nisso alicerçado, Chomsky $(1986,1988)$ enumerou cinco questões em meio às quais descreveu as metas centrais que deveriam nortear 0 empreendimento gerativo com base no seu programa intrinsecamente vinculado à ótica biolinguística, quais sejam, (1) o que é e a que corresponde o conhecimento da linguagem? ; (2) como é que o conhecimento da linguagem é adquirido? ; (3) como é que o conhecimento da linguagem é colocado em prática e em uso? ; (4) como é que o conhecimento da linguagem é implementado no cérebro? ; e (5) como o conhecimento da linguagem emerge nas espécies? (vide CHOMSKY, 1986, 1988 apud 
BOECKX; GROHMANN, 2007, p. 1; compare também RATTOVA, 2014a, p. 108, 2014b, p. 57-58).

Desde então, tais questionamentos têm constituído o coro central e se sedimentado como foco de inquirição nos diversos campos da Linguística Teórica tais como nas tradicionais áreas da Sintaxe, da Morfologia, Fonologia, Semântica e Pragmática, afora o que em outros ramos da ciência linguística a exemplo da Neurolinguística, da Psicolinguística, Linguística Computacional e Evolucionária ou Evolutiva. Disso, ocorre que, resguardadas as devidas divergências teóricas existentes, segundo entendimento histórico de Boeckx e Grohmann (2007), esses cinco pontos supracitados compreendem, afinal, tão somente variantes conceitualmente descompactadas que essencialmente se baseiam nas quatro grandes questões biológicas de Tinbergen (2005), um documento central na biologia do comportamento animal cujos quatro tópicos expressos em seu clássico artigo "On The Aims and Methods of Ethology" ("As Finalidades e Métodos da Etologia") foram originalmente propostos em 1963 e são estes cá descritos: (1') O que estimula o animal a responder com o comportamento que ele demonstra e o que são esses mecanismos responsivos? ; (2') como o organismo se desenvolve quando o indivíduo amadurece? ; (3') por que o comportamento é necessário para o sucesso do animal e como a evolução age sobre este comportamento? ; (4') como um comportamento em particular evoluiu através do tempo? E nós podemos traçar um comportamento comum entre duas espécies retroativamente com seus ancestrais comuns? (cf. BOECKX; GROHMANN, 2007, p. 1-2).

Apesar do paralelo biológico existente entre os questionamentos de ambos, a propósito, é importante destacar que os pontos de Tinbergen tão somente servem de base e norteiam a elaboração dos questionamentos de Chomsky, uma vez que este não compactua com determinados pontos daquele especialmente por serem eles de base fundamentalmente comportamentalista. Assim colocado, Chomsky especificamente combate, a título tanto explanatório quanto exemplificativo, o ponto (1') de Tinbergen que parte de respostas aos estímulos do meio justamente por naturalmente se opor ao modelo de estímulo-resposta de Skinner, além do que o ponto (4') que parte de uma evolução que se dá ao longo do tempo em razão de também ser contra a ideia de uma evolução gradual nos termos do darwinismo, sendo adepto de uma explicação evolutiva saltacional e de uma concepção puramente inatista da linguagem ${ }^{6}$ (cf. BERWICK; CHOMSKY, 2016), postulando não ser a gramática fruto da seleção natural, mas sim decorrente ou da ação de leis físicas (PINKER, 2002, p. 465-469) ou do processo alternativo de exaptação (FITCH, 2011) ou possivelmente de spandrel ${ }^{7} \quad(\mathrm{FITCH}, 2005$, p. 215217; HAUSER; CHOMSKY; FITCH, 2002; confronte com RATTOVA, 2014a, p. 103-104 e 109, 2014b, p. 49-72) a ponto de a linguagem ser compreendida como uma descontinuidade biológica (GONZÁLEZ, 2007) $)^{8}$. Para Chomsky, por assim dizer, o mais famoso linguista, como também para Gould, o mais conhecido paleontólogo do mundo, dentre outros

\footnotetext{
${ }^{6}$ Para informações adicionais e discussão complementar sobre inatismo e sua relação com a linguagem e o enfoque biolinguístico segundo a linha do minimalismo chomskyano e as considerações do Efeito Baldwin, queira acessar Longa (2014).

7 Conforme conceituado por Gould (1991), a exaptação compreende o fenômeno junto ao qual certos traços, então úteis a um dado organismo, os quais evoluíram por meio da seleção natural, são cooptados ou apropriados para assumir uma outra função de maneira tal que esta nova característica ou propriedade não exsurge como uma adaptação para o presente propósito, mas como um redirecionamento para cumprir uma nova função a fim de reforçar a aptidão do organismo enquanto que o spandrel remete aos casos, dentro da evolução, em que uma determinada estrutura ou propriedade emerge como consequência colateral de outro fenômeno evolutivo, configurando-se como subproduto de outra configuração arquitetônica (ver também BUSS; HASELTON; SHACKELFORD; BLESKE; WAKEFIELD, 1998, p. 539-540; GOULD; LEWONTIN, 1979; GOULD; VRBA, 1982).

8 Contraste as ideias de continuidade biológica de Pinker e Bloom (1990) e de Pinker (2002), que concebem a evolução da linguagem como darwiniana e, portanto, gradual e adaptativa, com a de González (2007) que defende a concepção de que a linguagem evoluiu a partir de uma emergência biológica, isto é, por intermédio de uma inovação espontânea que ocorre de modo quase instantâneo e relativamente rápido ao surgir de determinadas condições generativas as quais relativizam e/ou anulam o peso que certos fatores de caráter adaptativo, ditados pelo entorno, podem exercer na conformação de tais inovações. Acesse também Longa e Lorenzo (2014) para conhecer um modelo diferente de se explicar a natureza e evolução da linguagem, qual seja, o inerente ao da concepção de "self-organization" ("auto-organização") e para averiguar as principais diferenças dessa abordagem em relação à da seleção natural darwiniana que podem ser constatadas em uma tabela apresentada pelos autores a qual sumariza as principais diferenciações entre a selação natural e a auto-organização (q.v. p. 133).
} 
estudiosos, a linguagem não poderia ser produto da seleção natural, mas poderia sim ser um efeito colateral advindo de outras forças evolutivas tais como do aumento volumétrico do cérebro humano e das restrições impostas por leis ainda desconhecidas de estrutura e crescimento do organismo (PINKER; BLOOM, 1990, p. 2). Apesar das naturais diferenças epistêmicas, as similitudes entre as questões de um e outro tal como apresentadas e problematizadas são evidentes do ponto de vista basicamente de como apontar a importância biológica em termos evolutivos para a solução de questões relativas a determinados problemas postos, tal como muito bem frisado pelo editorial de Boeckx e Grohmann (2007) em seu manifesto biolinguístico e claramente discutido por Fitch (2005, p. 197-198) que aborda como as quatro questões de Tinbergen as quais podem ser distinguidas como quatro classes de perguntas inerentemente biológicas são igualmente importantes, cada uma delas, para o entendimento da evolução de qualquer trato de ordem biológica, inclusive da própria linguagem.

Com efeito, tamanho objetivo central do Gerativismo de determinar a caracterização da faculdade da linguagem ao prover seu desmembramento em uma série de questões que norteiam seu empreendimento enquanto escola linguística, como feito por Chomsky (1986, 1988), permitem ainda melhor compreender a sua perspectiva biolinguística em essência, para além do que a sua ótica psicolinguística obviamente. Assim, do mesmo jeito que os questionamentos chomskianos tais quais observados mais acima em (2) e em (3) denotam a natureza psicológica e, porquanto, psicolinguística do programa gerativo em seu cerne, as indagações tais como formuladas em (4) e em (5) expressam a identidade igualmente biológica e, por conseguinte, biolinguística da Linguística Generativa. Aliás, saliente-se que este quarto ponto particularmente também manifesta sutilmente 0 caráter evolucionista do projeto gerativista, demonstrando, outrossim, a estreita ligação, em essência, do Gerativismo com a Linguística
Evolucionária ou Evolutiva e consequentemente com a defesa do ponto de vista de Pinker e Bloom (1990) e de Pinker (2002) de rediscutir a linguagem como um instinto dentro do quadro da linguística contemporânea com base nas premissas do princípio da Seleção Natural de Darwin (2003), apesar das sabidas divergências teóricas existentes no nível mais elaborado e detalhado do quadro epistemológico e teórico do gerativismo frente à biolinguística strictu sensu e perante a Linguística Evolutiva. Dessa feita, relevante ainda é pontuar que todas essas questões, em suma, podem ser condensadas em uma só pergunta central tal qual exposta supra em (1) por Chomsky, o qual manifesta a perspectiva eminentemente linguística, além do que epistemológica e, quiçá, filosófica, por naturalmente estar mais associada à Linguística Teórica, o que acaba por finalmente demonstrar, assim, ser o projeto biolinguístico do gerativismo caracterizado por uma natureza múltipla de ordem tanto biolinguística quanto psicolinguística e sobremaneira linguística com respaldo inclusive filosófico (confer BOECKX; GROHMANN, 2007, p. 1; CHOMSKY, 1986, 1988).

Nesse diapasão, ressalte-se também que tal biolinguística de cunho lato sensu inerente ao programa gerativista de Chomsky, passa, por um lado, a não considerar importante 0 foco $e$ preocupação anterior retratado pela linguística moderna - a qual se centrava na avaliação e estudo da variação entre os sistemas linguísticos, isto é, entre as línguas ou idiomas propriamente ditos - à medida que, por outro lado, introduz, em seu lugar, a metáfora do desenvolvimento que, nos dizeres de Lewontin (2002, p. 10), significa "literalmente, o desdobrar ou desenrolar de algo que já está presente e em certo sentido pré-formado", sendo a função do ambiente, por sua vez, funcionar como gatilho desencadeador do começo desse processo ao providenciar as condições e recursos mínimos suficientes e necessários para 0 progresso dos estágios internamente programados pelo código genético do organismo ou indivíduo humano (LEWONTIN, 2002, p. 19). Isso naturalmente evidencia o caráter evolucionário dessa biolinguística 
lato sensu e retrata estar ela simbiótica e intimamente também identificada com a Linguística Evolucionária ou Evolutiva do ponto de vista estritamente elementar, reitere-se, de como se tem situado a linguagem enquanto fenômeno natural que detém uma contraparte evidentemente biológica. No geral, essas considerações lewontianas traduzem muito bem o que Chomsky define como sendo a faculdade da linguagem que naturalmente já vem anexada a e constituída por uma Gramática Universal (GU) ao mesmo tempo instanciadas no cérebro, psique e/ou cognição humanos conforme a ideia de GU começou a tomar forma a partir da conformação da Teoria de Princípios e Parâmetros (CHOMSKY, 1981) e a ser refinada e melhor caracterizada após o Programa Minimalista (CHOMSKY, 1995, 2007a, 2007c).

Nessa visada, consoante apontado por Pellegrino (2011, p. 37-39), a biolinguística neste sentido lato pode assumir uma abrangência ainda maior que não se restrinja unicamente a manter compatibilidade com o projeto da Linguística Gerativa, mas também como sendo um programa compatível com diversas outras disciplinas do ramo linguístico que trabalham com as bases bio-neurológicas da linguagem e com o seu desenvolvimento tanto ontogenético quanto filogenético, identificando-se, pois, com a Psicolinguística, com a Neurolinguística e com a própria Linguística Evolucionária ou Evolutiva. Nestes termos, a biolinguística encerra um projeto linguístico investigativo que também estaria identificado com os fatores que restringem, a título de ilustração, o desenvolvimento da linguagem humana nas crianças, com os processos neurofisiológicos envolvidos nas desordens linguísticas e na produção do discurso, com as bases biológicas das desordens da linguagem e do discurso, com os aspectos biológicos do desenvolvimento da linguagem nos infantes, com a determinação da estrutura e evolução das partes do cérebro e do sistema nervoso que lidam com a linguagem, com a transmissão genética da linguagem e com as precondições biológicas para o desenvolvimento e uso da linguagem nos seres humanos. Portanto, nesse sentido, a Biolinguística deve ser encarada como um projeto ou perspectiva teórica norteadora dos passos ou caminhos a serem trilhados por diferentes setores adjuntos e/ou doutrinariamente próximos da Linguística os quais procuram aproximá-la das ciências naturais.

Em outras palavras, também se faz preciso depreender que estas cinco questões inquiritivas centrais, tal como formuladas por Chomsky (1986, 1988), objetivam descrever biologicamente as propriedades da gramática com o comprometimento de seguir principiologicamente ${ }^{9}$ o lineamento teórico e metódico do Gerativismo chomskiano (vide PELLEGRINO, 2011) nos moldes do que fora proposto, de início, em LSLT no que concerne aos ideais do movimento gerativista de Chomsky (1975).

Por sua vez, naquele sentido mais estrito, a denominação "biolinguística" foi criada como reflexo da tentativa de certos setores específicos da Linguística em intentarem constituir, modelar e consolidar uma nova subárea especializada de estudos da linguagem que mantivesse estreito laço interdisciplinar com a Biologia - ou as Ciências Biológicas - com quem manteria intrínseca e oficial interface epistêmica e metodológica, a ponto de ser a Biolinguística ou Linguística Biológica um ramo ou subárea da Linguística, assim como os demais clássicos setores desta ciência já conhecidos.

Daí, essa diretriz originou-se embrionariamente em meados do século $X X$, tendo como seus genuínos precursores e patronos os pesquisadores Meader e Muyskens (1962) os quais foram os primeiros estudiosos a empregarem o termo "Biolinguística" que, na língua de origem dos referidos autores, notadamente o inglês, foi cunhado "Biolinguistics" (cf. DI SCIULLO; BOECKX, 2011b, p. 1). Foram eles que estabeleceram o pioneirismo ao publicarem a obra em crescente e vertiginoso sucesso desde aquela época, há cerca de 60 anos, até os dias de hoje "Handbook of Biolinguistics" ("Manual de Biolinguística") nos anos 50, mais precisamente no

9 Entenda-se "principiologicamente" como derivado de principiológico, aquilo que deriva de princípio, de um conjunto de princípios, e, por sua vez, de principiologia que corresponde ao conjunto dos princípios de determinada área, campo, ofício ou atividade. Assim, deseja-se reforçar a ideia de que o projeto biolinguístico em sua perspectiva lato sensu pretende comprometer-se em seguir o conjunto de princípios que regem o arcabouço teórico do Gerativismo Linguístico. 
mencionado ano de 1950 conforme citado em "nota sobre livro" por Matos (2011) e declarado por Boeckx e Grohmann (2007) em "The Biolinguistics Manifesto" ("O Manifesto Biolinguístico"): editorial de inauguração da primeira edição ou primeiro volume da revista e/ou periódico especializado em publicar pesquisas dessa área e o qual foi nomeado de "Biolinguistics" (veja BOECKX, 2013 para uma revisão histórica de como se deu o desenvolvimento do campo da Biolinguística; e, ao depois, confira WU, 2014 a fim de se obter uma visão geral e/ou overview das pesquisas desenvolvidas na área ${ }^{10}$ ).

Nessa direção, embora apenas há pouco o jornal tenha sido lançado, tão somente em idos de 2007, já havia o interesse, manifestado por Lyle Jenkins, de criar uma revista própria de "biolinguística" desde a década de 70. Afinal, foi ela, após algumas décadas de latência e dormência de atuação e expansão do campo de estudos da Biolinguística, a responsável pelo forte ressurgimento da área, pelo renascimento do interesse nela e pela retomada da focalização das pesquisas em biolinguística, inclusive pela retomada da utilização do termo "biolinguística", fazendo-o reaparecer após algumas décadas de seu encobrimento, a partir de seu artigo "Biolinguistics - Structure, development and evolution of language" em 1997 e de seu livro "Exploring the Biology of Language" nos anos 2000 (q.v. JENKINS, 2000). Desde então, a área tem crescentemente se consolidado especialmente a partir da publicação do artigo de Jenkins (1997) a versar sobre a estrutura, desenvolvimento e evolução da linguagem o qual pavimentou o terreno de progresso no campo de estudos acerca da estrutura ontogenética e filogenética do desenvolvimento da

\footnotetext{
${ }^{10}$ Examine também Di Sciullo e Boeckx (2011a) que focalizam a discussão sobre a história do progresso e das atuais perspectivas do projeto biolinguístico lato sensu também conhecido como biolinguística chomskyana, defendendo 0 ponto de vista desta corrente biolinguística. Estude, da mesma forma, Pennisi e Falzone (2016) que focam o debate em torno da história e desenvolvimento da biolinguística strictu sensu enquanto área independente, bem delimitada e interdisciplinar, argumentando em favor da biolinguística darwiniana, aquela que está alinhada ao Evolucionismo, ou seja, à Teoria da Evolução e da Seleção Natural de Darwin inerente à Biologia Evolucionária a cuja corrente Steven Pinker e Paul Bloom inclusive estão integrados e que consequentemente é a linha que respalda a fundamentação deste trabalho ao qual necessariamente ele se vincula.
}

linguagem na seara inerentemente biolinguística, tendo havido, como desdobramento disso, não só o surgimento do periódico Biolinguistics, mas também do Laboratory for Biolinguistics (Laboratório para Biolinguística) que foi inaugurado e se estabeleceu no Riken Brain Science Institute (Instituto de Ciências do Cérebro de Riken), além do que foi fundado e estabelecido o The Grup de Biolingüística-GB (O Grupo de Biolinguística-GB) na Universidade de Barcelona (PELLEGRINO, 2011, p. 29-30). Demais, curiosamente a aparição, no título daquele livro, publicado a partir de 1950 , do nascente nome "Biolinguística", correspondeu à origem e à primeira vez em que o termo foi empregado na literatura técnica especializada. Por outro lado, quase duas décadas depois, o lançamento da obra "Biological Foundations of Language" revelou o pai da Biolinguística $^{11}$, dessa nova área do conhecimento, a saber, Eric Lenneberg ${ }^{12}$, em 1967, que suficientemente delimitou e expandiu o escopo caracterizador de investigação do referido setor (CHOMSKY, 2004, 2005; DI SCIULLO; BOECKX, 2011b, p. 1-2; LENNEBERG; CHOMSKY; MARX, 1967; RIZZI, 2004; TRETTENBREIN, 2017).

Todavia, apenas em 1974 houve a ascensão e, bem dizer, o nascimento oficial do campo intitulado como tal a partir da ocorrência e concretização da seminal reunião interdisciplinar, promovida no MIT (Massachusetts Institute of Technology) nos EUA entre linguistas, biólogos (especialmente biólogos evolucionários), neurocientistas e outros acadêmicos preocupados com a linguagem e a biologia (cf. CHOMSKY, 2004, p. 1, 2005, p. 1, 2007b, p. 2), em torno do que ficou conhecido como o primeiro congresso de biolinguística oficialmente realizado

\footnotetext{
${ }^{11}$ A fim de uma incursão mais detalhada e de um estudo e/ou análise explanatória geral e mais introdutória sobre a perspectiva inerente à Biolinguística, leia a obra de Maria Carlota Rosa, o livro brasileiro "Introdução à (bio)linguística: linguagem e mente" (ROSA, 2013).

${ }^{12}$ Acesse Trettenbrein (2017) para inteirar-se mais contextualizada e pormenorizadamente da história de exsurgimento do estudo das bases biológicas da linguagem sob a ótica biolinguística implementada por Lenneberg (1967). Este editorial tanto retrata a biografia de Lenneberg (TRETTENBREIN, 2017, p. 22-23) quanto relata as circunstâncias históricas de criação e lançamento do livro "Biological Foundations of Language" ("Fundações Biológicas da Linguagem") do referido autor (TRETTENBREIN, 2017, p. 23-25).
} 
sob os cuidados e organização de Massimo Piattelli-Palmarini (PIATTELLI-PALMARINI, 1974) a fim de atender à anteriormente idealizada convocação do evento por parte de Salvador Luria e de Noam Chomsky sob a tutela do Centro Royaumont para As Ciências Humanas (BOECKX; GROHMANN, 2007; CHOMSKY, 2004, 2005, 2007c; DI SCIULLO; PIATTELLI-PALMARINI; WEXLER; BERWICK; BOECKX; JENKINS; URIAGEREKA; STROMSWOLD; CHENG; HARLEY; WEDEL; McGILVRAY; VAN GELDEREN; BEVER, 2010; RATTOVA, 2014b, p. 50; TRETTENBREIN, 2017). Além disso, esse evento inaugurador também foi seguido pela conferência sobre "Modelos Filogenéticos e Ontogenéticos do Desenvolvimento Cognitivo" ("Ontogenetic and Phylogenetic Models of Cognitive Development') realizado em Paris em 1975 e também organizado por Piattelli-Palmarini (cf. JENKINS, 2008, p. 342).

No entanto, muito embora a biolinguística quer seja como área interdisciplinar em sentido strictu sensu quer seja enquanto programa identificado com - gerativismo linguístico em caráter lato sensu tenha exsurgido em meados do século $X X$, os estudos essencialmente de natureza biolinguística, ressalte-se, que se preocupavam em desvendar as origens e a evolução da linguagem humana (vide YULE, 1998 para uma introdução às origens da linguagem ${ }^{13}$ ), começaram bem antes já no início do século XIX a partir do advento da Linguística Histórico-Comparativa com seu método comparativo de reconstrução das línguas antigas, mortas e primordiais a qual visava principalmente reconstruir a

\footnotetext{
13 Yule (1998, p. 11-19) introduz uma explanação sobre as possibilidades de origem da linguagem humana em seu livro, procurando retratar as mais diversas teorias que tentam explicar como a linguagem surgiu entre os seres humanos. Importante se faz consultá-lo para se conhecer abordagens teóricas distintas da darwinista, naturalmente gradual e adaptacionista, tais como a da Hipótese do Som Natural, da Glosogenética, da Adaptação Fisiológica e da Interação e Transação. Também é significativo checar Yule (1998, p. 42-51) para se conhecer melhor acerca da relação existente entre a linguagem humana e os animais, ou seja, para se começar a entender o relacionamento que existe entre a linguagem própria do homem e os sistemas de comunicação animal. Além de tudo, notório se faz, da mesma forma, verificar Rosa (2013, p. 60-72) que também relata os estudos de ordem linguística que têm sido desenvolvidos com animais ao longo de todo o século $X X$ ao questionar, ao longo de sua abordagem, se é possível, por exemplo, ensinar uma certa língua a um determinado animal.
}

protolíngua e desvendar a origem da linguagem humana, bem como os meios pelos quais ela evoluiu até atingir o aspecto atual da época em questão. Esses propósitos demonstram, pois, como a Linguística Clássica era profundamente caracterizada por uma postura assaz biolinguística e evolucionária que permite identificá-la como a primeira escola linguística a compartilhar de um perfil com objetivos semelhantes aos das atuais disciplinas da Biolinguística e da Linguística Evolucionária ou Evolutiva. Nesse sentido, o pioneiro dos estudos biolinguísticos, antes mesmo que a Biolinguística se constituísse como uma ciência independente em meados do século XX e até mesmo antes que Darwin propusesse a sua Teoria da Evolução e da Seleção Natural, foi o notável linguista alemão August Schleicher (1821-1868) o qual bastante discutiu e muito esgrimiu acerca da evolução da linguagem através da ótica da teoria evolucionista darwiniana ao examinar a linguagem a partir da perspectiva da Biologia Evolucionária durante o período do método histórico-comparativo em linguística no século XIX (cf. WU, 2014, p. 173).

Tendo sido retratado, porquanto, o histórico de surgimento da área, convém, por conseguinte, tratar dos objetivos e da natureza principiológica da Biolinguística. Assim sendo, a biolinguística traduz-se como o ramo da linguística que estuda a linguagem humana como sendo uma característica ou propriedade biológica do ser humano e até mesmo um órgão mental/cerebral ${ }^{14}$ que é concebido, administrado e controlado pela biologia do ser. Em outras palavras, a Biolinguística é uma ciência biológica que mantém interface com a Biologia e com a Linguística, considerando esta também como uma

\footnotetext{
14 Muito embora "órgão" e "cerebral" remetam ao que é fisiológico e "mental" ao que é psicológico, ao se falar em "órgão mental/cerebral" se está procurando enfatizar que a linguagem, apesar de sua relativa abstração, pode e deve ser estudada que nem os demais atributos da espécie humana biologicamente investigados os quais, diga-se, são mais concretos e fisiologicamente observáveis conforme perfeitamente destacado por Boeckx e Grohmann (2007, p. 1) e por Fujita (2009, p. 128) o qual também, este, descreve a linguagem, saliente-se, como sendo um "órgão mental/biológico". Além do mais, destaque-se que o próprio Chomsky $(2005$, p. 1) se refere à faculdade da linguagem, por exemplo, como sendo um "órgão do corpo" juntamente com outros sistemas cognitivos, destacando que essa acepção provém da perspectiva biolinguística de estudo da linguagem humana.
} 
ciência natural do mesmo jeito que aquela. Investiga se os princípios regentes da língua(gem $)^{15}$ são típicos e exclusivos deste sistema cognitivo em específico ou se se aplicam e, por consequência, se ampliam para outros domínios da cognição humana ou para outros organismos animais de uma maneira tal a apresentarem (estes animais) arranjos formais similares aos do módulo linguístico intrínseco ao homem.

Enfim, ela analisa em que consiste a natureza orgânica e biológica da linguagem em seus níveis anatômicos, fisiológicos e mentais e/ou neuronais, além do que 0 processo de aquisição, desenvolvimento e maturação tanto bioquímica quanto biológica pelo qual passa a faculdade da linguagem nos termos do definido na tradição gerativa chomskyana. Em última instância, averigua a contraparte genética responsável pela constituição e configuração arquitetônica da linguagem tomada por meio do viés dessa faculdade de acordo com o estabelecido pela corrente biolinguística strictu sensu (DI SCIULLO et. al., 2010; ROSA, 2013).

\footnotetext{
15 Quando se usa a nomenclatura "língua(gem)" consoante estabelecida pelas tradutoras brasileiras Averburg e Souza quando da tradução realizada da obra inglesa de Lyons (2009), deseja-se, ao mesmo tempo, se referir tanto à faculdade da linguagem, isto é, à linguagem humana em seu caráter universal, considerada uma forma de linguagem, assim como se busca aludir às línguas naturais humanas naturalmente amplas em suas diversidades e peculiaridades, ainda que alicerçadas sobre a linguagem eminentemente universal. O próprio Lyons (2009), apesar da restrição imposta por sua língua nativa, o inglês, que apresenta unicamente a palavra "language" para se referir tanto à "língua" quanto à "linguagem", debate essa questão tomando por base a dicotomia existente em outras línguas tais como o francês e o espanhol a título exemplificativo, que demonstram possuir, tal como o português, no inventário de seus idiomas, os termos franceses "langue" (língua) e "langage" (linguagem) e os espanhóis "lengua" (língua) e "lenguaje" (linguagem) respectivamente. Desse modo, quando as tradutoras decidem utilizar a forma de expressão "língua(gem)" a partir das assunções teóricas de Lyons (2009), elas almejam expressar, assim como eu cá busco fazer, os casos em que se é possível tratar, considerar e falar seja da língua seja da linguagem, isto é, de ambas simultaneamente e de maneira indissociável segundo o que procurou empreender Lyons (2009) em suas discussões, a fim de deixar transparente os casos em que este expunha tal necessidade de se estabelecer essa indissociabilidade. Em face disso, utilizo a expressão "língua(gem)" justamente para transmitir a ideia de linguagem incorporada indissociavelmente às línguas naturais quando se procura analisar seus fundamentos sob uma perspectiva biolinguística.
}

\section{Possível Contribuição da Concepção Instintiva da Linguagem, em face de sua Plausível Interface com a Biolinguística e com a Linguística Evolucionária, para a Psicolinguística}

A priori, apesar das divergências geradas dentro da ótica gerativista, a contribuição particularmente que Pinker e Bloom (1990) e Pinker (2002) conferem aos estudos linguísticos, e especialmente às explorações biolinguísticas as quais inserem a Linguística no seio das ciências naturais, foi de reacender $o$ debate $e$ atualizar contemporaneamente como ninguém a consideração da linguagem humana como sendo mais que um órgão mental/cerebral ou uma faculdade intrinsecamente sedimentada na mente e cérebro do homem de tal sorte a ser considerada um instinto tal como inicialmente aventado por Darwin em seu clássico livro "The Descent of Man, and selection in relation to sex" ("A Descendência do Homem, e A Seleção em Relação ao Sexo") em 1871 (q. v. DARWIN, 1889; PINKER, 2002, p. 11-14). Com isso, Steven Pinker retoma modernamente, no início da década de 90 e, portanto, em fins do século XX, a idealização da linguagem como instinto primeiramente a partir da publicação de seu influente artigo em conjunto com Paul Bloom em 1990 (PINKER; BLOOM, 1990) e depois por meio do lançamento de seu livro "The Language Instinct" ("O Instinto da Linguagem") em 1994, trazendo tal conceptualização instintiva da linguagem para o seio de discussão da Linguística, e não tão somente mais para a Biologia como tivera feito Darwin no século XIX a partir da divulgação à época da obra "On The Origin of Species" ("A Origem das Espécies") originalmente publicada em 1859. Em assim sendo, o autor traz para o entorno do debate linguístico essa idealização de linguagem enquanto instinto ao reavivar a concepção de que ela, por ser um instinto, é uma habilidade biológica sujeita às pressões da Seleção Natural e, porquanto, ao fenômeno da 
adaptação $^{16}$ (cf. DARWIN, 2003), um dos componentes nucleares e essenciais para o processo de evolução das espécies, de suas arquiteturas, de seus órgãos, funções e habilidades vitais ${ }^{17}$. Em face disso, Pinker e Bloom (1990) e Pinker (2002) acabam por expor a linguagem como sendo um objeto de investigação que naturalmente pode e/ou deve estar circunscrito dentro do espeque da Linguística Evolucionária de tal modo que tais autores e especialmente Steven Pinker têm contribuído inclusive para ajudar a revigorar, pelo menos nas últimas três décadas, essa área da Linguística que esteve dormente por quase um século ${ }^{18}$ (vide PINKER, 2002, p. 5-17).

Por conseguinte, como argumentado por Pinker e Bloom (1990) e Pinker (2002), se é uma propriedade instintiva oriunda de programações e/ou atualizações genéticas em âmbito tanto genotípico quanto fenotípico, é de se esperar que, assim como os demais atributos orgânicos de todos os seres

16 Segundo Buss et. al. (1998, p. 535-538), a "adaptação" compreende o fenômeno relativo à herança de uma característica herdada hereditariamente a qual surge como uma propriedade das espécies vivas sob ação direta do processo de seleção natural, compreendendo uma inerente característica desenvolvimental que surge em uma espécie através desse processo seletivo, permitindo, de forma direta ou indireta, a facilitação da reprodução dos organismos de tais espécies viventes durante o período de trajetória evolutiva (ver GOULD, 1991).

${ }^{17}$ Um reputado levantamento das doutrinas de Pinker, relativas à consideração da linguagem humana como um instinto, além do que um estudo ou explanação comparativa estabelecida com a perspectiva do sistema de representação mental de base inata de Chomsky, pode ser visualizado a partir da confrontação estabelecida pela dissertação de mestrado de Rattova (2014b) e de seu correspondente artigo (RATTOVA, 2014a) entre estas duas correntes doutrinárias de pensamento, a pinkeriana e a chomskyana.

18 Com vistas a tomar conhecimento da profunda influência que Darwin exerceu sobre a teoria linguística nos séculos XIX e XX e como recentemente o darwinismo e conceitos como "seleção natural", "progresso" e "teleologia" estão fortemente influenciando a teorização linguística contemporânea a qual tem reacendido a defesa das abordagens evolucionárias da linguagem, leia Pickering (2011). Além disso, uma pertinente discussão acerca das teorias sobre evolução da linguagem disseminadas no cerne da Linguística Evolucionária ou Evolutiva de caráter neodarwinista e orientadas conforme a abordagem adaptacionista é levantada por Gontier (2012) a qual debate a respeito do foco da área em responder a questões em torno da caracterização do que seja a linguagem e para que ela evoluiu à medida que levanta sérias e agudas críticas sobre a necessidade de se priorizar também a focalização em como essa evolução se tem dado e procedido, questão que, segundo a autora, tem sido negligenciada pelos linguistas evolucionários. Enfim, esquadrinhe Navarro (2008) que debate o problema da origem da linguagem a partir de uma perspectiva evolucionista, elucidando os meios pelos quais ocorreu o seu desenvolvimento segundo a ótica darwinista da Linguística Evolucionária ou Evolutiva. vivos, a linguagem humana esteja, de algum modo, vinculada e/ou correlacionada à Teoria Evolucionista de Darwin (2003) e passível de sofrer as interveniências multidimensionais das forças próprias e advindas da Seleção Natural. Particularmente Pinker (2002), reatualizando Darwin na defesa desta tese, declara então que à linguagem é imputada a operância de três propriedades, princípios ou leis aplicáveis aos seres vivos e organismos biológicos do mesmo jeito que o é em relação a outros conjuntos de entidades com suas respectivas características biológicas, quais sejam, (1ํ) 0 da multiplicação que precisa o desacordo ou divergência de caracteres ou elementos e está intimamente associada à extinção de formas menos desenvolvidas ou aperfeiçoadas, $\left(2^{\circ}\right)$ o da variação ou variabilidade que é naturalmente originada da ação ou direta ou indireta das condições de existência do organismo ou ser e $\left(3^{\circ}\right)$ o da hereditariedade que acarreta bem dizer a lei de reprodução dos organismos ou entes (ver DARWIN, 2003, p. 19-227, 523-554 para o entendimento destes três conceitos relativos às leis e/ou princípios da multiplicação, variação e hereditariedade de modo contextualizado dentro do quadro da Teoria Evolucionista da Seleção Natural).

\section{A título de explanação para posterior} compreensão linguística, conforme conceitua Pinker (2002, p. 457), por multiplicação entende-se a capacidade que essas entidades detêm de produzirem cópias de si mesmas e que as cópias também são capazes de se autorreplicarem. Com relação à variação, esta implica dizer que esse processo de cópia não é perfeito, nem infalível e que, ao passar das épocas ou eras, falhas inesperadamente surgem durante o processo de replicação, de modo tal que esses erros acabam por poder conferir traços a essas entidades que lhes permitam se multiplicar mais ou menos rapidamente. Já a hereditariedade refere-se à condição de que um traço variante emergido por um erro de cópia inevitavelmente reaparece em cópias subsequentes de maneira que ela se perpetua na linhagem ao longo das gerações (cf. PINKER, 2002, p. 457). 
Em face disso, essas três propriedades, segundo arguido por Pinker (2002, p. 458-459), conectam duas ideias que, inobstante serem independentes e bastante diferentes, são complementares e interdependentes para se sustentarem enquanto grandezas vivas e/ou operantes. São elas: $1^{\underline{a}}$ ) a aparência de design, a princípio, que deve ser compreendida como a estrutura através da qual as suas partes constituintes estão meticulosamente organizadas e ordenadas com vistas a exercer determinada função ou papel de modo que as partes de um organismo parecem ser projetadas para fomentar com sucesso sua reprodução. E, a posteriori, $2^{\underline{a}}$ ) as estatísticas atuariais de reprodução nos ancestrais do organismo, uma ideia que implica na assunção de que os ancestrais deste organismo reproduziam-se outrora mais eficientemente que seus rivais. Trata-se, pois, de um projeto de engenharia interconectado a taxas de nascimento e morte em que esta ( $2^{\underline{a}}$ concepção) se traduz na causa e explicação daquela (1 $\left.{ }^{a}\right)$. Isso feito, apenas traços que atendam às demandas desse processo podem ser confirmados como sendo produtos da seleção natural e, em virtude disso, resultados da evolução.

Vê-se, dessa forma, que especificamente Pinker (2002) se apropria de conceitos oriundos da Teoria Evolucionista e da Seleção Natural concebidas no bojo das ideias do teórico e biólogo Darwin para explicar a natureza, o funcionamento e evolução da linguagem humana, caracterizando-a como um instinto e assemelhando-a a outros órgãos ou organismos sujeitos às leis da evolução e seleção. É assim que Steven Pinker, ressalvadas as importantes contribuições de Paul Bloom, então assimilou à Linguística tanto as leis referentes às três propriedades mencionadas (multiplicação, variação e hereditariedade) quanto as duas ideias (aparência de design e estatísticas atuariais) advindas do darwinismo, sendo por essa razão consagrado como o pai do novo campo da Linguística Evolucionária juntamente com Paul Bloom, haja vista que a publicação do influente artigo de Pinker e Bloom (1990) "Natural language and natural selection" na prestigiada revista científica "Behavioral and Brain Sciences", tradicional periódico de Psicologia, Neurologia, Neurociências e de Ciências Naturais e Biológicas, em 1990 foi o responsável por marcar a origem desse novo campo inter e transdisciplinar também conhecido hoje em dia como Linguística Evolucionária ou Evolutiva (cf. GONTIER, 2012, p. $69)$.

Assim, provando-se que a linguagem humana diacronicamente perpassou através das eras sofrendo a ação operante dessas três variáveis ou entidades seletivas pertinentes à evolução, tem-se a condição necessária e suficiente para se afirmar que a comunicação humana em sentido mais geral e a linguagem em consideração mais restrita são produtos ou elaborações decorrentes da Seleção Natural, isto é, talentos ou manifestações oriundos da evolução do mesmo jeito que outras engrenagens orgânicas vivas; e que a língua é, de fato, um instinto como sustentam Pinker e Bloom (1990) e Pinker (2002) segundo uma abordagem centrada na corrente ou escola da biolinguística darwiniana notadamente associada à biolinguística strictu sensu e que não está afinada, esclareça-se, com o projeto biolinguístico chomskyano interligado e/ou harmonizado à biolinguística lato sensu em torno do que foi mais acima discutido na sessão anterior ${ }^{19}$.

\footnotetext{
${ }^{19}$ É significante esclarecer que há uma divergência teórica entre Chomsky e Pinker sobre questões biolinguísticas relacionadas à natureza da linguagem humana, de seu trajeto evolutivo, da maneira como ela é adquirida e como ela se desenvolve e se desenvolveu no Homo Sapiens. Por um lado, Chomsky, desde 1959, defende a concepção de que a linguagem é caracterizada por uma gramática universal de sustentação inata que provavelmente se desenvolveu por exaptação e/ou spandrel ao passo que Pinker, desde 1990, advoga em favor da ideia de que ela é um espécime de instinto em evolução que certamente evoluiu por adaptação e por meio da operacionalização da seleção natural. Destaque-se, inclusive, que esse desacordo se tem refletido e culminado em um longo e extenso debate entre ambas as visões epistêmicas - qual pode ser constatado nos recentes embates desencadeados entre Hauser, Chomsky e Fitch (2002) e Fitch, Hauser e Chomsky (2005) vs. Pinker e Jackendoff (2005) e Jackendoff e Pinker (2005) cuja discussão dos principais pontos de conflito das duas orientações epistemológicas e de seu impacto sobre os rumos da biolinguística é tratada em Campos (2011). Em face dessa discordância, tão somente reclamo e reitero que a biolinguística de Chomsky se assemelha à de Pinker ao longo das alegações e do arrazoado deste artigo no que concerne ao fato de ambos arrazoarem sobre a linguagem ser um fenômeno biológico, advogando ambos uma compreensão biológica acerca da linguagem humana. Em todo caso, esteja devidamente esclarecido que a percepção da biolinguística que fundamenta este artigo está centrada na linha defendida por Pinker relativa à biolinguística strictu sensu de
} 
Mas, como esses postulados podem ser úteis à Psicolinguística e à condução de suas inquerições e atividades? A questão é que, em verdade, toda essa ponderação pode ser muitíssimo útil e viável!

Primeiramente, partindo-se da concepção evolutiva de multiplicação (cf. DARWIN, 2003, p. 75148), caso se prove que a linguagem é um complexo que evolui, tem evoluído e continuará a evoluir com o passar do tempo - porque, por se comportar como qualquer outro organismo ou espécie e como qualquer uma de suas partes biologicamente constituintes (células, tecidos, órgãos, cognição, habilidades etc.), consequentemente acaba por ficar e estar subjugada à Seleção Natural em torno de um quadro que the confere realmente o status de órgão e, para além disso, de instinto - concluir-se-á que ela detém as propriedades da multiplicação e, por consequência desta, da variação e também da hereditariedade nela vigentes de uma maneira naturalmente forte e constantemente atuantes no seu desenvolvimento sincrônico e diacrônico (compare com SAUSSURE, 2006 para compreender a diferença da perspectiva da sincronia e diacronia nos estudos linguísticos).

Se assim for, à medida que os estudos psicolinguísticos forem se desenvolvendo e se expandindo até o ponto de conseguir pelo menos chegar perto de serem capazes de descrever e explicar qual a natureza e que processos mentais e cognitivos são subjacentes à estruturação, compreensão, aquisição e processamento linguístico da linguagem humana, projetada por meio dos diversificados idiomas existentes no mundo, dentro da mente e/ou psique e especialmente da cognição humanoide, poder-se-á concluir que esses processos são relativamente homogêneos e que, pela propriedade da multiplicação supramencionada, eles se mantêm estáveis e quase que imutáveis ao longo das gerações, haja vista que os possíveis genes responsáveis pela tradução das proteínas que

caráter darwiniano, sendo esta concepção de língua(gem) do enfoque biolinguístico e característico da Linguística Evolucionária ou Evolutiva a utilizada para explicar como a conceptualização da linguagem como instinto pode contribuir para o desenvolvimento e avanço da área interdisciplinar da Psicolinguística. atuarão sobre o organismo humano, inclusive no sistema nervoso e na região cerebral, e possuidores da correta e detalhada programação a ser implementada na constituição das faculdades mentais, cognitivas e, obviamente, linguísticas serão autorreplicantes, possuindo a capacidade de automultiplicarem sua programação e identidade programática a fim de ser passada aos descendentes no decorrer da linhagem reprodutiva dos organismos e espécies; o que implicará entender que as computações linguísticas correntes na mente e/ou cognição de um indivíduo são as mesmas para outro que viva no mesmo ponto temporal da história, como também para outros - pelo menos em essência e não consideradas as duas outras entidades a serem explicadas logo mais - os quais sejam detentores das mesmas regras e leis dos seres humanos que tenham sido viventes de outros períodos históricos desde que a faculdade da linguagem surgiu entre os primeiros homens dotados dela (q. v. PINKER, 2002, p. 95149).

Por sua vez, com relação à variação, a linguagem, que tecnicamente estaria, por conta da multiplicação, imune a alterações em suas programações e estruturas, permanecendo como entidade imutável e totalmente imaculada não importasse quanto tempo ou períodos se passassem, pode apresentar-se potencialmente suscetível a variações ou mudanças conjunturais de suas engrenagens e parcelas cuidadosamente construídas. Logo, durante as replicações decorrentes das reproduções dos organismos humanos, os genes causadores, em última instância, da linguagem, por serem promotores do alicerçamento neural e das partes orgânicas infraestruturais que possibilitam à língua sistematicamente se organizar em nível cognitivo, de maneira mais abstrata e superior, podem adquirir novos traços diferentes dos precedentes ou antigos, devido a imperfeições ou falhas no momento da replicação, em que as entidades copiam a si mesmas, numa inédita conjuntura que pode fornecer meios para que as replicações posteriores possam acontecer numa velocidade ou mais lenta ou mais rápida em 
comparação com outras entidades homólogas de mesma raiz original ou procedimento histórico (cf. DARWIN, 2003, p. 19-74, 149-183).

Com efeito, isso implica dizer que, em certas classes ou grupos humanos, pode ser que haja, em dada época da história, uma variação ou mutação das entidades (dentre as quais se situam as delineadoras da linguagem) durante a replicação delas no transcurso das reproduções sexuadas de parceiros humanos, que geraria novos comportamentos linguísticos distintos e diferenciados dos de outros grupos que ainda não passaram por essas variações (mantendo a arquitetura primária mais arcaica) ou que sofreram mutações de natureza distinta. Ocorre então que tais acontecimentos acarretam uma competição entre as entidades divergentes e os grupos humanos distintos que igualmente se reproduzem, gerando replicações genéticas continuamente, num ciclo infinito, e que, vez ou outra, se cruzam a ponto de fazerem com que uma das variações apenas prevaleça com o passar das gerações, levando a outra à extinção, ou a ponto de combinarem, na mesma proporção, forças que gerem outra mutação e que façam com que ambas se extingam para dar vazão a outro novo ente.

De fato, para a Psicolinguística, isso é, outrossim, sobremodo relevante porque, havendo uma descrição e explicação fenomenal ou fenomenológica $^{20}$ dos processos computacionais, mentais e/ou cognitivos e linguísticos, consoante explicitado logo acima, pela presença da variação enquanto entidade genética, haverá justificativa lógica

20 Fenomenológico compreende 0 adjetivo relativo à Fenomenologia, abordagem filosófica que surgiu com Edmund Husserl (1859-1938) na Alemanha no final do século XIX e princípio do século $X X$ a qual visa o estudo dos fenômenos, de tudo aquilo que aparece à consciência, almejando estabelecer o laço que une dado fenômeno com o ser de que é fenômeno e o Eu para quem é fenômeno conforme aponta Palmer (1999). Sendo a fenomenologia a ciência da essência do conhecimento, a doutrina universal das essências, o método da crítica do conhecimento universal das essências e se considerando que tem por tarefa analisar de maneira esclarecedora a estrutura dos fenômenos da consciência (HUSSERL, 2008), emprego o termo fenomenológico aqui, com base nisso, para designar tudo aquilo relativo a fenômeno psicológico ou mental e mais precisamente ao fenômeno que está sendo estudado, a saber, o linguístico sob uma abordagem biolinguística e evolutiva (que naturalmente envolve a interface com a consciência interna do homem) a partir de uma atitude reflexiva e cujas descrições e explicações são baseadas na investigação tal como procura fazer o método científico (cf. GALEFFI, 2000; OLIVEIRA e SILVA; LOPES; DINIZ, 2008). e biológica fundamentada para dar conta das discrepâncias existentes, que tenham existido ou que possam vir a existir futuramente entre os mesmos processos linguísticos processuais e arquitetônicos a nível quer mental quer cognitivo - aqueles que seguem os mesmos princípios ou que têm o mesmo caráter constitutivo entre grupos distintos que porventura falem o mesmo idioma (de etnias, raças e origens distintas por exemplo) ou entre línguas diversas faladas por diferentes povos (qd. vid. PINKER, 2002, p. 379-424).

Finalmente, em se tratando da hereditariedade, as diferenças, na transmissão genética entre os organismos das espécies, as quais suscitam 0 surgimento de novos traços naturais, oriundas das falhas advindas das respectivas replicações que fugiram do padrão e protocolo funcional rigidamente delimitado, ou seja, que sofreram mutação, tendem por continuar a ser transmitidas ao longo das gerações pelo princípio da hereditariedade o qual garante que variações de traços originais que resultam em traços secundários ou derivados se agreguem à programação genética dos organismos e acabem por se sedimentar com o passar do tempo no próprio código programático genético da espécie como um todo (cf. DARWIN, 2003, p. 23-28, 279282).

Destarte, se a linguagem é um produto decorrente desses três processos justamente por estar à mercê da Seleção Natural, ela deve ter suas propriedades caracterizadoras, estruturantes e constitutivas sendo regidas por esses mesmos princípios que dirigem os órgãos ou sistemas vivos presentes na natureza e sob o jugo dela. Por essa razão, é natural que historicamente a linguagem tenha passado por metamorfoses e mutações que geraram constantes e lineares mudanças em suas propriedades ou características essenciais, levando-a a evoluir e a jamais se estagnar em torno de uma sistemática ou orgânica estável, rígida e inalterável; contudo, pelo contrário, está condenada a eternamente ter seus constituintes transformados através de contínuas mutações originadas das falhas que conduzem indubitavelmente à variação em um 
ciclo infinito de alterações metamórficas sobremaneira garantidos e reforçados pela hereditariedade.

Assim sendo, isso oportunamente garante à Psicolinguística respaldo para, tanto em contextos sincrônicos quanto diacrônicos, poder justificar de forma coerente as diferenças processuais existentes no concernente aos falantes de várias línguas, os quais estejam imersos em um só continuum cronológico ou numa mesma dimensão ou paradigma temporal, como também confere base para responder às semelhanças entre elas, afora o que para explicar diferenças computacionais de certos fenômenos ou manifestações linguísticas dentro do seio de uma comunidade linguística quando comparadas às populações de dada época passada x com a de um período presente y ou ainda de um posterior $z$ (qd. vid. PINKER, 2002, p. 425-476).

Além do mais, futuramente, caso desvendem e decodifiquem os traços primordiais que compuseram a protolíngua, será tecnologicamente possível, desde que paleontológica e arqueologicamente os códigos e programações genéticas, hoje extintos, possam ser, com o auxílio da Engenharia Genética, da Química, da Física, da Matemática, da Paleontologia, da Arqueologia, da Antropologia, da Computação, da Inteligência Artificial, da Filologia e da Tecnologia juntamente com a Nanotecnologia, virtualmente remodelados e reconstruídos para que assim possibilitado seja se estabelecerem as conexões diretas entre a programação a priori fornecida e a linguagem dela gerada como produto. Justamente pelo fato de a Linguística Evolucionária ou Evolutiva necessitar do aporte teórico-metodológico de todas essas áreas e ciências para auxiliar em seu avanço técnico-científico é que ela é essencialmente um campo de estudos, desde sua origem, não somente interdisciplinar, mas também multidisciplinar e transdisciplinar, por estar em constante diálogo com as mais diversas e diferenciadas ciências das mais diferentes naturezas.

Desse modo, torna-se possível classificar e sistematicamente inventariar as diversas estruturas da linguagem em termos processuais e computacionais, ou seja, psicolinguísticos, nos mais diversos períodos do tempo, traçando-se "um verdadeiro raio- $X$ (fotografia por meio dos raios $X$ ou Raios Roentgen em termos metafóricos) da anatomia e fisiologia da linguagem em cada época, inclusive na de hoje ${ }^{21}$ a fim de radiografá-la". De certo, havendo a cartografia de todas as propriedades da língua, em grau evolutivo, a qual é atualmente utilizada pelos falantes reais, os quais pelo mundo estão espalhados, será possível testar como essas propriedades linguísticas estão pareadas, em relação tanto de correlação quanto de causalidade, a traços ou propriedades genéticas constitutivas da espécie humana e como estas repercutem ou intervêm nos meios ou recursos cognitivos empregados para proceder com o processamento da linguagem e das suas estruturas, bem como da manifestação e projeção seja virtual seja real daquelas tais propriedades, afora o que será factível desvendar como elas influem no funcionamento do parser ${ }^{22}$, dos

${ }^{21}$ Sendo a fisiologia o estudo das funções mecânicas, físicas e bioquímicas e, porquanto, orgânicas dos seres vivos, dos seus processos vitais e do funcionamento do organismo, compreenda-se por fisiologia da linguagem o estudo e a compreensão do funcionamento da linguagem e das funções que permitem explicitar a sua identidade enquanto fenômeno linguístico. De igual maneira, considerando-se a anatomia o estudo da estrutura interna e externa do corpo humano ou de qualquer ser vivo, da organização estrutural das formas de vida, - que inclui seus sistemas, órgãos e tecidos, além das substâncias de que são feitos, entenda-se por anatomia da linguagem a investigação de suas estruturas integrantes, ou seja, da sua natureza estrutural. Quando menciono, pois, "traçar um verdadeiro raio- $X$ da anatomia e fisiologia da linguagem a fim de radiografá-la", esteja entendido por essa metáfora que será futuramente possível, por assim dizer, tanto descrever quanto explicar a natureza, a estrutura e o funcionamento da linguagem, além de sua origem e evolução filogenética e ontogenética dentro de um processo muito semelhante ao observado quando se tira um raio-X de alguma estrutura corporal para verificar os detalhes de sua conformação estrutural, de suas partes anatômicas constituintes e dos seus processos fisiológicos em funcionamento por intermédio de tal radiografia. Portanto, tirar um raio-X da anatomia e fisiologia da linguagem significa esquematizar e radiografar todo o esqueleto estrutural, funcional e, por conseguinte, identitário da linguagem, a ponto de que se torne cabível delinear um quadro explicativo do que seja, de fato, a linguagem, de como ela se conforma "anatomicamente", quer dizer, no tocante à sua estrutura e de que modo ela se organiza "fisiologicamente", i.é., em termos funcionais.

22 O "parser" compreende um tipo de processador ou computador mental, presente na mente/cérebro de cada ser humano, responsável por analisar e processar a sintaxe dos enunciados linguísticos com vistas a permitir sua compreensão. Tal jargão alude, pois, a esse espécime de dispositivo ou "órgão" cognitivo responsável pelas operações sintáticas primitivas tais como aquelas responsáveis pela indicação dos papéis sintáticos e temáticos, decodificação da ordem sintático-estrutural dos elementos linguísticos em termos sentenciais, decomposição da estrutura de constituintes sintagmáticos e computação da grade argumental dos verbos a 
processadores sintático e semântico (quod vide PINKER, 2002, p. 523-558).

A partir disso, enfim, por comparação às características processuais da linguagem atual e por dedução retroativa, possa ser que num futuro ainda distante (no que agora indubitavelmente é ficção) tenhamos capacidade de catalogar minuciosamente, descrever e explicar como se davam os processamentos em diferenciadas épocas do passado, em que diferem e/ou diferiam da linguagem dos dias atuais e que percurso seguiram à medida que as mudanças foram ocorrendo e sendo implementadas (cf. PINKER, 2003).

\section{Considerações Finais}

Observou-se brevemente, ao longo deste estudo reflexivo, o trajeto histórico traçado por duas importantes áreas especializadas das Ciências Linguísticas, a saber, a Psicolinguística (OSGOOD; SEBEOK, 1954a, 1954b, 1965) e a Biolinguística (MEADER; MUYSKENS, 1962) com sucintas considerações acerca da Linguística Evolucionária ou Evolutiva e de sua forte inter-relação com este ramo biológico da Linguística sob a luz da perspectiva da concepção instintiva da linguagem pinkeriana (PINKER, 2002; PINKER; BLOOM, 1990) a qual, biolinguisticamente, insere, ao estudo da língua(gem) humana, as conceptualizações teóricas de diversos setores interdisciplinares a ela, a exemplo da Genética, Engenharia Genética, Medicina, Neurociências, Biologia, Paleontologia, Arqueologia, Antropologia, Nanotecnologia e, especialmente, da Teoria Evolucionista da Seleção Natural darwiniana (DARWIN, 2003), considerando a linguagem inerentemente como um instinto (DARWIN, 1889).

A partir disso, refletiu-se a respeito do possível valor atual e, deveras, da crescente importância futura que venha ainda mais a assumir a defesa conceitual que Pinker e Bloom (1990) e Pinker (2002) fazem da linguagem como instinto humano fundamentado nas raízes biológicas e evolutivas do

partir do reconhecimento dos seus argumentos externos e internos depois de se ter iniciado e concluído o decurso do processamento linguístico. homem para o campo de estudos e escopo de investigações e/ou inquirições da Psicolinguística enquanto ramo da Linguística ao retomar de Darwin (1889) tal idealização da linguagem como força instintiva.

Na sequência, ponderou-se como os conceitos existentes por detrás das entidades e/ou princípios darwinianos nomeados de multiplicação, variação e hereditariedade são incorporados na Linguística e ajustados mais pontualmente à Biolinguística e à Linguística Evolucionária ou Evolutiva as quais Pinker e Bloom (1990) e Pinker (2002) encabeçam tanto em suas reflexões quanto em suas investigações perquiritivas. Mostrou-se como tais autores, notavelmente Pinker, sabiamente entrelaçam e associam as leis e princípios inerentes à Teoria da Seleção Natural de Darwin (2003) ao espeque linguístico, revelando que a linguagem humana é regida, segue e se estrutura em torno dessas mesmas leis evolucionistas, as que regem a evolução dos organismos vivos e, ao que tudo indica, as línguas naturais e a faculdade da linguagem tipicamente intrínseca ao homem.

Por fim, retratou-se como o conceito que permeia esses três entes e/ou princípios no tocante aos seus ajustamentos, adaptações e/ou acomodações ao campo biolinguístico e próprio da Linguística Evolucionária ou Evolutiva são pertinentes e podem ser válidos, além do que extremamente úteis para o entendimento e explicação dos fenômenos linguísticos, cognitivos e processuais imanentes à Psicolinguística e ao seu escopo de investigações.

Em suma, pode-se concluir que a comprovação e descrição sumária de que essas três entidades são presentes e operantes sobre a sistemática organizacional e complexo funcionamento da linguagem humana, bem como em torno da projeção funcional das línguas naturais dela derivadas possibilitará - dentro de um paradigma de efeito cascata ou dominó, por consequência lógica e por análise dedutiva, afora o que empírica - associar os fundamentos, leis e/ou princípios tanto norteadores quanto reguladores da aquisição da linguagem e do processamento linguístico, correntes na psique ou na 
mente e principalmente sobre a cognição dos seres humanos, a essas três entidades e, por efeito, às forças dirigentes e preceitos governantes do processo de Seleção Natural nos moldes da Teoria Evolucionista darwiniana a qual demonstra os meios pelos quais a evolução das espécies e organismos viventes sobre a face da terra ocorre.

Enfim, espera-se, pois, que se prove futuramente, com o avanço técnico, tecnológico e teórico-científico, e até mesmo epistemológico, que essas associações são verdadeiras e passíveis de serem realizadas de sorte que as relações causais, que se cogita existirem entre as partes acá averiguadas, sejam estabelecidas como reais, demonstrando, portanto, que a sistematização operacional e as propriedades de estruturação e funcionamento não apenas biológico, mas também evolutivo da linguagem, em termos biolinguísticos, sejam, em igual medida e em relação proporcional, aplicáveis à organização e gama de características definidoras da manifestação psíquica e cognitiva da faculdade da linguagem e das línguas naturais as quais subjazem e alicerçam a sua aquisição e o seu processamento sob o enfoque psicolinguístico.

\section{Referências}

ALTMANN, Gerry T. M. History of psycholinguistics. In: BROWN, Keith (Ed.). Encyclopedia of language \& linguistics. $2^{\text {nd }}$ ed. Boston: Elsevier, 2006. 9000 p. 14 v. p. $257-265$.

The language machine: psycholinguistics in review. British Journal of Psychology, Malden, MA, v. 92, n. 1, p. 129-170, fev. 2001.

BALIEIRO-Jr., Ari Pedro. Psicolingüística. In: MUSSALIM, Fernanda; BENTES, Anna Christina (Org.). Introdução à lingüística: domínios e fronteiras. v. 2. 5. ed. São Paulo: Cortez, 2006. 270 p. p. $171-202$.

BERWICK, Robert C.; CHOMSKY, Noam. Why only us: language and evolution. Cambridge, MA: MIT Press, 2016. 224 p.

BLOOMFIELD, Leonard. Language history: from language. New York: Holt, Rinehart and Winston, 1965. $512 \mathrm{p}$.

BOECKX, Cedric. Biolinguistics: forays into human cognitive biology. Journal of Anthropological Sciences, Roma, v. 91, p. 63-89, 2013.
; GROHMANN, Kleanthes K. The biolinguistics manifesto. Biolinguistics, Nicosia, v. 1, p. 1-8, outono 2007.

BUSS, David M. et. al. Adaptations, exaptations, and spandrels. American Psychologist, Washington, D.C., v. 53, n. 5, p. 533-548, maio 1998.

CAMARA JÚNIOR, Joaquim Mattoso. História da linguística. 7. ed. Petrópolis: Vozes, 2011. 238 p.

CAMPOS, Jorge. Chomsky vs Pinker: na interface entre linguística e psicologia evolucionária. Letras de Hoje, Porto Alegre, v. 46, n. 3, p. 12-17, jul./set. 2011.

CEZARIO, Maria Maura; MARTELOTTA, Mário Eduardo. Aquisição da linguagem. In: MARTELOTTA, Mário Eduardo (Org.). Manual de linguística. 2. ed. São Paulo: Contexto, 2012. 254 p. p. 207-216.

- VOTRE, Sebastião. Sociolinguística. In: MARTELOTTA, Mário Eduardo (Org.). Manual de linguística. 2. ed. São Paulo: Contexto, 2012. 254 p. p. 141-155.

CHOMSKY, Noam. Approaching UG from below. In: SAUERLAND, Uli; GÄRTNER, Hans-Martin (Ed.). Interfaces + recursion = language? Chomsky's minimalism and the view from syntax-semantics. Berlin: Mouton de Gruyter, 2007a. 289 p. p. 1-30.

Aspects of the theory of syntax. Cambridge, MA: MIT Press, 1965. 261 p.

Biolinguistic explorations: design, development, evolution. International Journal of Philosophical Studies, Abingdon, Oxon, v. 15, n. 1, p. 1-21, mar. 2007b.

Knowledge of language: its nature, origin, and use. Westport, CT: Praeger, 1986. 307 p.

Language and problems of knowledge: the Managua Lectures. Cambridge, MA: MIT Press, 1988. 216 p. (Current Studies in Linguistics, 16).

Lectures on government and binding. $2^{\text {nd }}$ ed. Dordrecht: Foris, 1981. 371 p.

Logical structure of linguistic theory (LSLT). New York: Springer, 1975. 592 p.

Of minds and language. Biolinguistics, Nicosia, v. 1, p. 9-27, outono 2007c.

Syntactic structures. $2^{\text {nd }}$ ed. Berlin: Walter de Gruyter, 2002. 117 p.

The biolinguistic perspective after 50 years. QDLF - Quaderni del Dipartimento di Linguistica, Firenze, v. 14, p. 3-12, 2004. 
The minimalist program. Cambridge, MA: MIT Press, 1995. 420 p.

Three factors in language design. Linguistic Inquiry, Cambridge, MA, v. 36, n. 1, p. 1-22, winter 2005.

CHRISTIANSEN, Morten H.; CHATER, Nick. Connectionist psycholinguistics: capturing the empirical data. TRENDS in Cognitive Sciences, London, v. 5, n. 2, p. 82-88, fev. 2001.

CORRÊA, Letícia Maria Sicuro. Possíveis diálogos entre teoria lingüística e psicolingüística: questões de processamento, aquisição e do déficit específico da linguagem. In: MIRANDA, Neusa Salim; NAME, Maria Cristina Lobo (Org.). Lingüística e Cognição. Juiz de Fora: Editora da UFJF, 2005. 343 p. p. 221-244.

COSTA, Marcos Antonio. Estruturalismo. In: MARTELOTTA, Mário Eduardo (Org.). Manual de linguística. 2. ed. São Paulo: Contexto, 2012. 254 p. p. 113-126.

DARWIN, Charles. A origem das espécies. Porto: Lello \& Irmão, 2003. 572 p. Disponível em: $<$ http://ecologia.ib.usp.br/ffa/arquivos/abril/darwin1. pdf>. Acesso em: 20 jun. 2018.

The descent of man, and selection in relation to sex. New York: D. Appleton \& Company, 1889. 688 p. Disponível em: $<$ http://darwin-online.org.uk/converted/pdf/1889_D escent_F969.pdf>. Acesso em: 20 jun. 2018.

DI SCIULLO, Anna Maria et. al. The biological nature of human language. Biolinguistics, Nicosia, v. 4, n. 1, p. 4-34, inverno 2010.

BOECKX, Cedric (Ed.). The biolinguistic enterprise: new perspectives on the evolution and nature of the human language faculty. New York: Oxford University Press, 2011. 559 p. (Oxford Studies in Biolinguistics, v. 1).

Introduction: contours of the biolinguistic research agenda. In: (Ed.). The biolinguistic enterprise: new perspectives on the evolution and nature of the human language faculty. New York: Oxford University Press, 2011. 559 p. p. 1-16.

FERRARI-NETO, José; SILVA, Cláudia Roberta Tavares (Org.). Programa minimalista em foco: princípios e debates. Curitiba, PR: CRV, 2012. 306 p.

FITCH, W. Tecumseh. The evolution of language: a comparative review. Biology and Philosophy, Dordrecht, v. 20, n. 2-3, p. 193-230, mar. 2005.

The evolution of syntax: an exaptationist perspective. Frontiers in Evolutionary Neuroscience, Lausanne, v. 3, artigo 9, p. 1-12, dez. 2011.
; HAUSER, Marc D.; CHOMSKY, Noam. The evolution of the language faculty: clarifications and implications. Cognition, Amsterdam, v. 97, n. 2, p. 179-210, set. 2005.

FONSECA, Rívia Silveira. Aristóteles e a linguagem: estudo e tradução do Perì hermeneías (partes 16). 2009. $122 \mathrm{f}$. Tese (Doutorado em Linguística) Instituto de Estudos da Linguagem, Universidade Estadual de Campinas, 2009.

FUJITA, Koji. A prospect for evolutionary adequacy: merge and the evolution and development of human language. Biolinguistics, Nicosia, v. 3, n. 23, p. 128-153, primavera-verão 2009.

FURTADO DA CUNHA, Angélica. Funcionalismo. In: MARTELOTTA, Mário Eduardo (Org.). Manual de linguística. 2. ed. São Paulo: Contexto, 2012. 254 p. p. 157-176.

COSTA, Marcos Antonio; MARTELOTTA, Mário Eduardo. Linguística. In: MARTELOTTA, Mário Eduardo (Org.). Manual de linguística. 2. ed. São Paulo: Contexto, 2012. 254 p. p. 15-29.

GALEFFI, Dante Augusto. O que é isto - a fenomenologia de Husserl? Ideação, Feira de Santana, n. 5, p. 13-36, jan./jun. 2000.

GONTIER, Nathalie. Selectionist approaches in evolutionary linguistics: an epistemological analysis. International Studies in the Philosophy of Science, Abingdon, Oxon, v. 26, n. 1, p. 67-95, mar. 2012.

GONZÁLEZ, Guillermo José Lorenzo. ¿Descenso o emergencia?: claves para comprender el lenguaje como una discontinuidad biológica. Archivum: Revista de la Facultad de Filología, Oviedo, v. 57, p. 139-168, 2007.

GOULD, Stephen Jay. Exaptation: a crucial tool for an evolutionary psychology. Journal of Social Issues, Hoboken, NJ, v. 47, n. 3, p. 43-65, set. 1991.

; LEWONTIN, Richard Charles. The spandrels of San Marco and the Panglossian paradigm: a critique of the adaptationist programme. Proceedings of The Royal Society Series BBiological Sciences, London, v. 205, n. 1161, p. 581-598, set. 1979 .

VRBA, Elisabeth S. Exaptation: a missing term in the science of form. Paleobiology, New York, v. 8, n. 1, p. 4-15, winter 1982.

HARLEY, Trevor A. The psychology of language: from data to theory. $3^{\text {rd }}$ ed. Hove: Psychology Press, 2008. 624 p.

HAUSER, Marc D.; CHOMSKY, Noam; FITCH, W. Tecumseh. The faculty of language: what is it, who has it, and how did it evolve? Science, 
Washington, D.C., v. 298, n. 5598, p. 1569-1579, nov. 2002.

HUSSERL, Edmund. $A$ ideia da fenomenologia. Lisboa: Edições 70, 2008. 136 p.

JACKENDOFF, Ray; PINKER, Steven. The nature of the language faculty and its implications for evolution of language (Reply to Fitch, Hauser, and Chomsky). Cognition, Amsterdam, v. 97, n. 2, p. 211-225, set. 2005.

JENKINS, Lyle. Biolinguistics - structure, development and evolution of language. In: Online Conference "The 40-th Anniversary of Generativism", 1., 1997, Kazan (on-line). Anais... Kazan: Web Journal of Formal, Computational \& Cognitive Linguistics, 1997. p. 1-24. Disponível em: <http://fccl.ksu.ru/papers/gp008.pdf>. Acesso em: 22 jun. 2018. Paper.

Exploring the biology of language. Cambridge: Cambridge University Press, 2000. $264 \mathrm{p}$.

Not the only word. Biolinguistics, Nicosia, v. 2, n. 4, p. 342-347, fall 2008.

KENEDY, Eduardo. Gerativismo. In: MARTELOTTA, Mário Eduardo (Org.). Manual de linguística. 2. ed. São Paulo: Contexto, 2012. 254 p. p. 127-140.

KESS, Joseph F. On the developing history of psycholinguistics. Language Sciences, Oxford, v. 13, n. 1, p. 1-20, jan./abr. 1991.

LEITÃO, Márcio Martins. Psicolinguística experimental: focalizando o processamento da linguagem. In: MARTELOTTA, Mário Eduardo (Org.). Manual de linguística. 2. ed. São Paulo: Contexto, 2012. 254 p. p. 217-234.

LENNEBERG, Eric H.; CHOMSKY, Noam; MARX, Otto. Biological foundations of language. New York: John Wiley \& Sons, 1967. 528 p.

LEWIS, Shevaun; PHILLIPS, Colin. Aligning grammatical theories and language processing models. Journal of Psycholinguistic Research, New York, v. 44, n. 1, special issue, p. 27-46, fev. 2015.

LEWONTIN, Richard Charles. A tripla hélice: gene, organismo e ambiente. São Paulo: Companhia das Letras, 2002. 144 p.

LONGA, Víctor M. Genes, lenguaje e innatismo: algunas precisiones. Letras, Lima, v. 84, n. 119, p. 99-122, jan./jun. 2014.

; LORENZO, Guillermo. Self-organization and natural selection: the intelligent auntie's vademecum. Biolinguistics, Nicosia, v. 8, p. 130-140, 2014.
LYONS, John. Linguagem e lingüística: uma introdução. Tradução de Marilda Winkler Averburg e Clarisse Sieckenius de Souza. Rio de Janeiro: LTC, 2009. 269 p. Tradução de: Language and Linguistics.

MACLAY, Howard. Linguistics and psycholinguistics. In: KACHRU, Braj B. et. al. (Ed.). Issues in Linguistics: papers in honor of Henry and Renee Kahane. Urbana: University of Illinois Press, 1973. 938 p. p. $569-587$.

MAIA, Marcus (Org.). Psicolinguística, psicolinguísticas: uma introdução. São Paulo: Contexto, 2015. 208 p.

MARTELOTTA, Mário Eduardo (Org.). Manual de linguística. 2. ed. São Paulo: Contexto, 2012. 254 p.

PALOMANES, Roza. Linguística cognitiva. In: MARTELOTTA, Mário Eduardo (Org.). Manual de linguística. 2. ed. São Paulo: Contexto, 2012. 254 p. p. $177-192$.

MATOS, Francisco Gomes de. Introdução à (bio)linguística: linguagem e mente. DELTA, São Paulo, v. 27, n. 1, p. 169-173, 2011. Nota sobre Livro.

MEADER, Clarence L.; MUYSKENS, John $H$. Handbook of biolinguistics. Toledo: Herbert C. Weller, 1962. $173 \mathrm{p}$.

MILLER, George A. Language and communication. New York: McGraw-Hill, 1951. 320 p.

The cognitive revolution: a historical perspective. TRENDS in Cognitive Sciences, London, v. 7, n. 3, p. 141-144, mar. 2003.

CHOMSKY, Noam. Finitary models of language users. In: LUCE, Robert Duncan; BUSH, Robert R.; GALANTER, Eugene (Ed.). Handbook of mathematical psychology. New York: John Wiley \& Sons, 1963. v. 1. 491 p. p. 2-419.

; SELFRIDGE, Jennifer A. Verbal context and the recall of meaningful material. The American Journal of Psychology, Champaign, v. 63, n. 2, p. 176-185, abr. 1950.

MURRAY, David J. On the early history of psycholinguistics. Historiographia Linguistica, Amsterdam, v. 17, n. 3, p. 369-381, set./dez. 1990.

NAVARRO, Raymundo Casas. Darwin, la evolución y el languaje. Letras, Lima, v. 79, n. 114, p. 139-148, jan./dez. 2008.

O'CONNELL, Daniel C.; KOWAL, Sabine. Psycholinguistics: a half century of monologism. 
The American Journal of Psychology, Champaign, v. 116, n. 2, p. 191-212, summer 2003.

OLIVEIRA e SILVA, Jovânia Marques de; LOPES, Lúcia Mendonça; DINIZ, Normélia Maria Freire. Fenomenologia. REBEn - Revista Brasileira de Enfermagem, Brasília, v. 61, n. 2, p. 254-257, mar./abr. 2008.

OLIVEIRA, Mariangela Rios de. Linguística textual. In: MARTELOTTA, Mário Eduardo (Org.). Manual de linguística. 2. ed. São Paulo: Contexto, 2012. 254 p. p. 193-204.

; WILSON, Victoria. Linguística e ensino. In: MARTELOTTA, Mário Eduardo (Org.). Manual de linguística. 2. ed. São Paulo: Contexto, 2012. 254 p. p. 235-242.

OSGOOD, Charles E.; SEBEOK, Thomas A. (Ed.). Psycholinguistics: a survey of theory and research problems. Baltimore: Waverly Press, 1954a. 212 p.

(Ed.). Psycholinguistics: a survey of theory and research problems with a survey of psycholinguistic research, 1954-1964, by A. Richard Diebold and the psycholinguists, by George A. Miller. Bloomington: Indiana University Press, 1965. 307 p.

Psycholinguistics: a survey of theory and research problems. The Journal of Abnormal and Social Psychology, Washington, D.C., v. 49, n. 4, parte 2, p. 1-203, out. 1954b.

PALMER, Richard E. Hermenêutica. Lisboa: Edições 70, 1999. 284 p.

PELLEGRINO, Elisa. Investigations on the referential status of biolinguistics. A comparative overview of publications and lexicography. Lingue $e$ Linguaggio, Lecce, v. 10, n. 1, p. 29-56, jan./jun. 2011.

PENNISI, Antonino; FALZONE, Alessandra. Darwinian biolinguistics: theory and history of a naturalistic philosophy of language and pragmatics. Cham, Switzerland: Springer, 2016. 301 p. (Perspectives in Pragmatics, Philosophy \& Psychology, v. 12).

PETERFALVI, Jean-Michel. Introdução à psicolinguística. São Paulo: Cultrix; São Paulo: EDUSP, 1970. 142 p.

PIATTELLI-PALMARINI, Massimo. A debate on biolinguistics. Dedham, Ma, 1974. Conferência realizada na MIT Endicott House sob patrocínio do Centre Royaumont pour une science de l'homme report, entre 20-21 maio 1974.

PICHEVIN, Claude. L'acquisition de la compétence entre 2 et 4 ans. Psychologie Française, Paris, v. 13, p. 175-186, 1968.
PICKERING, William A. A influência de Darwin na teoria linguística como um prelúdio às abordagens "evolucionárias" no século 21. In: BERNARDO, Sandra; AUGUSTO, Marina R. A.; VASCONCELLOS, Zinda (Org.). Linguagem: teoria, análise e aplicações. v. 6. Rio de Janeiro: Programa de Pós-graduação em Letras - UERJ, 2011. 485 p. p. $105-124$.

PINKER, Steven. Language as an adaptation to the cognitive niche. In: KIRBY, Simon; CHRISTIANSEN, Morten H. (Ed.). Language evolution: states of the art. New York: Oxford University Press, 2003. 414 p. p. 16-37.

O instinto da linguagem: como a mente cria a linguagem. São Paulo: Martins Fontes, 2002. 627 p.

BLOOM, Paul. Natural language and natural selection. Behavioral and Brain Sciences, New York, v. 13, n. 4, p. 707-726, dez. 1990.

JACKENDOFF, Ray. The faculty of language: what's special about it? Cognition, Amsterdam, v. 95, n. 2, p. 201-236, mar. 2005.

RATTOVA, Sidriana Scheffer. A faculdade da linguagem como sistema de representação de base inata ou um instinto? Fólio - Revista de Letras, Vitória da Conquista, v. 6, n. 1, p. 103-119, jan./jun. 2014a.

A recursividade no sistema sintático subjacente à faculdade da linguagem. 2014. $81 \mathrm{f}$. Dissertação (Mestrado em Letras) - Programa de Pós-Graduação em Letras, Faculdade de Letras, Pontifícia Universidade Católica do Rio Grande do Sul, Porto Alegre, 2014b.

RIZZI, Luigi. On the study of the language faculty: results, developments, and perspectives. The Linguistic Review, Berlin, v. 21, n. 3-4, p. 323-344, set. 2004.

ROSA, Maria Carlota. Introdução à (bio)linguística: linguagem e mente. São Paulo: Contexto, 2013. 207 p.

SAUSSURE, Ferdinand de. Curso de linguística geral. 27. ed. São Paulo: Cultrix, 2006. 278 p.

SCLIAR-CABRAL, Leonor. Introdução à psicolingüística. São Paulo: Ática, 1991. 191 p.

SHANNON, Claude E.; WEAVER, Warren. The mathematical theory of communications. Urbana: University of Illinois Press, 1963. $117 \mathrm{p}$.

SKINNER, Burrhus Frederic. Verbal behavior. New York: Appleton-Century-Crofts, 1957. 486 p. 
. Verbal behavior. New York: Appleton-CenturyCrofts, 1957.486 p. Resenha de: CHOMSKY, Noam. Language, Washington, D.C., v. 35, n. 1, p. 26-58, jan./mar. 1959.

TINBERGEN, Niko. On aims and methods of ethology. (Reprinted from Zeitschrift fur Tierpsychologie, vol. 20, pg. 410, 1963), Animal Biology, Leiden, v. 55, n. 4, p. 297-321, dez. 2005.

TRETTENBREIN, Patrick C. 50 years later: a tribute to Eric Lenneberg's Biological Foundations of Language. Biolinguistics, Nicosia, v. 11, special issue, p. 21-30, 2017. Preprint.

WU, Jieqiong. An overview of researches on biolinguistics. Canadian Social Science, Québec, v. 10, n. 1, p. 171-176, fev. 2014.

YULE, George. El lenguaje. Traducción de Nuria Bel Rafecas. Madrid: Cambridge University Press, 1998. 354 p. Tradução de: The Study of Language.

\section{COMO CITAR ESSE ARTIGO}

MACHEL-NABOT, Pablo Silva de Almeida. Contribuições da Concepção Instintiva da Linguagem inerente à Biolinguística e à Linguistica Evolucionária para as pesquisas da Psicolinguística. Signo, Santa Cruz do Sul, v. 43, n. $77, \quad$ p. 160-183, maio 2018. ISSN 1982-2014. Disponível em: <https://online.unisc.br/seer/index.php/signo/article/view/11632>. Acesso em:_._ doi: https://doi.org/10.17058/signo.v43i77.11632. 